\title{
Enhancement of Locomotor Activity and Conditioned Reward to Cocaine by Brain-Derived Neurotrophic Factor
}

\author{
Brian A. Horger, Christiana A. Iyasere, Melissa T. Berhow, Chad J. Messer, Eric J. Nestler, and Jane R. Taylor \\ Laboratory of Molecular Psychiatry, Departments of Psychiatry, Pharmacology, and Neurobiology, Yale University School \\ of Medicine and Connecticut Mental Health Center, New Haven, Connecticut 06520
}

The mesolimbic dopamine (DA) system has been implicated in drug reward, locomotor sensitization, and responding for reward-related stimuli [termed conditioned reinforcers (CR)]. Here, we investigated the effect of brain-derived neurotrophic factor (BDNF), which enhances the survival and function of dopaminergic neurons, on stimulant-induced locomotor sensitization and responding for CR. In experiment 1 , BDNF was infused into the nucleus accumbens (NAc) or ventral tegmental area over 2 weeks via chronically implanted minipumps (1-2.5 $\mu \mathrm{g} / \mathrm{d})$, and the psychomotor stimulant effects of cocaine (5-15 $\mathrm{mg} / \mathrm{kg}$, i.p.) were studied. We found that BDNF enhanced the initial stimulant effects of cocaine and seemed to facilitate the development of sensitization to repeated cocaine doses. In experiment 2, we studied the effects of intra-NAc BDNF infusions on responding for CR. BDNF-treated rats showed twice as many $\mathrm{CR}$ responses compared with controls when saline was first administered. BDNF enhanced responding on the CR lever more than four times that seen in control animals after a cocaine injection $(10 \mathrm{mg} / \mathrm{kg}$, i.p.). The enhanced response to cocaine in BDNF-treated animals persisted for more than a month after the BDNF infusions had stopped, indicating longlasting changes in the mesolimbic DA system caused by BDNF administration. In experiment 3 , we examined locomotor sensitization to cocaine in heterozygous BDNF knock-out mice and found that the development of sensitization was delayed compared with wild-type littermates. These results demonstrate the profound effects of BDNF on the enhancement of both cocaineinduced locomotion and facilitation of $\mathrm{CR}$ and suggest a possible role for BDNF in long-term adaptations of the brain to cocaine.

Key words: BDNF; conditioned reward; psychomotor stimulant sensitization; mesolimbic dopamine system; nucleus accumbens, ventral tegmental area
Brain-derived neurotrophic factor (BDNF), a member of the nerve growth factor (NGF)-related family of neurotrophins, supports the survival and function of midbrain dopamine (DA) neurons in vivo and in vitro (Hyman et al., 1991; Altar et al., 1992; Shen et al., 1994; Shults et al., 1994; Spina et al., 1992). BDNF utilizes the TrkB receptor-protein tyrosine kinase as the primary means of signal transduction, and mRNA for both BDNF and TrkB are widely expressed in the rat forebrain, including DA cell body regions and their terminal fields (Ip et al., 1992; Loughlin and Fallon, 1993; Seroogy and Gall, 1993; Stephens et al., 1994; Kawamoto et al., 1996; Schmidt-Kastner et al., 1996; Siuciak et al., 1996; Frank et al., 1997; Numan and Seroogy, 1997). Behavioral studies have found that local administration of BDNF or other neurotrophic factors can augment nigrostriatal dopaminergic functioning and locomotor behavior (Altar et al., 1992; Martin-Iverson et al., 1994, 1996; Shen et al., 1994; Hebert et al., 1996; Horger et al., 1998). However, the impact of BDNF on behavior associated with the mesolimbic DA system has yet to be determined.

The mesolimbic DA system, composed of DAergic neurons in

Received Dec. 23, 1998; revised Feb. 22, 1999; accepted March 2, 1999.

This work was supported by United States Public Health Service Grants DA10160 and DA08227 and by the Abraham Ribicoff Research Facilities of the Connecticut Mental Health Center, State of Connecticut Department of Mental Health and Addiction Services. We thank Valyphone Phantharangsy for her excellent technical assistance and J. David Jentsch and David W. Self for valuable comments.

Correspondence should be addressed to Dr. Jane R. Taylor, Yale University School of Medicine, SHM B227, 333 Cedar Street, New Haven, CT 06520.

Dr. Horger's present address: Department of Neuroscience, 1 DNA Way, Genentech, South San Francisco, CA 94080.

Copyright @ 1999 Society for Neuroscience $0270-6474 / 99 / 194110-13 \$ 05.00 / 0$ the ventral tegmental area (VTA) and their projections to the nucleus accumbens (NAc) and other forebrain structures, has been implicated in the reinforcing and locomotor-activating properties of cocaine (Bozarth and Wise, 1986; Wise and Bozarth, 1987; Liebman and Cooper, 1989; Kuhar et al., 1991; Koob, 1992; Kalivas et al., 1993). Moreover, adaptations in the mesolimbic DA system after repeated exposures to drugs of abuse have been suggested to underlie motivational aspects of drug addiction (Koob and Le Moal, 1997; Nestler and Aghajanian, 1997). Interestingly, several interactions have been demonstrated between BDNF and adaptations to chronic drug exposure. Administration of BDNF directly into the VTA prevents several characteristic biochemical changes normally elicited by cocaine or morphine in the VTA and NAc (Berhow et al., 1995). Intra-VTA BDNF also prevents the effects of chronic morphine on the morphology of VTA DA neurons (Sklair-Tavron et al., 1996). In addition, chronic cocaine or morphine administration alters the functioning of specific proteins in the intracellular signaling cascades that mediate BDNF action (Berhow et al., 1996). Together, these findings suggest that BDNF and drugs of abuse, such as cocaine, may regulate the mesolimbic DA system in part through converging cellular pathways and that BDNF may thereby influence the reinforcing and locomotor activating properties of cocaine.

The aim of this study was to test this hypothesis by examining the effects of BDNF on locomotor activity and responding for conditioned reinforcers (CR). Stimulant-induced locomotor activation and sensitization, characterized by the progressive increase in locomotor activity resulting from repeated drug exposure, appears to be dependent on mesolimbic DAergic trans- 
mission (Kalivas and Stewart, 1991; Kalivas, 1993; Robinson and Berridge, 1993). The role of DA in the incentive motivational effects of stimulant drugs, measured by enhanced responding for CR, also has been demonstrated (Taylor and Robbins, 1984, 1986; Robbins et al., 1989; Everitt and Robbins, 1992). CR are originally neutral stimuli that gain incentive properties by their association with primary reinforcers. In the present study, we demonstrate profound effects of BDNF infusions on the locomotor and incentive motivational effects of cocaine.

\section{MATERIALS AND METHODS}

\section{Animals}

Male Sprague Dawley rats (initial weight of 250-275 gm) were used in these studies (Camm, Wayne, NJ). The animal colony was climatecontrolled and kept on a $12 \mathrm{hr}$ light/dark cycle. They were housed in pairs in plastic cages with corn chip bedding with food and water made available ad libitum, except for the CR study. For the CR study, animals' water was restricted to $30 \mathrm{~min} / \mathrm{d}$ after training or testing sessions, except during surgery and recovery. This caused rats to be maintained at $\sim 80 \%$ of initial free-feeding weight $(\sim 280-350 \mathrm{gm})$ throughout the experiments. Food was available ad libitum in the home cage. Weights were monitored daily.

Mice were male and female heterozygous BDNF knock-out mice, and controls were wild-type littermates obtained from Regeneron Pharmaceuticals (Tarrytown, NY) (Korte et al., 1995; Vaidya et al., 1999). Heterozygotes were used because homozygous knock-outs are not viable. The BDNF knock-out mice were heavier than their littermate controls, weighing $\sim 35 \mathrm{gm}$ compared with $25 \mathrm{gm}$. They were $\sim 6$ months old and were housed by litter, not by genotype; each cage contained approximately half BDNF knock-out animals and half control animals. The colony room was climate-controlled and kept on a $12 \mathrm{hr}$ light/dark cycle, with food and water made available ad libitum.

\section{Intracranial surgical procedures}

Minipumps $(0.5 \mu \mathrm{l} / \mathrm{hr}$ for $14 \mathrm{~d}$; Alzet model 2002, Alza Scientific Products, Palo Alto, CA) were filled $24 \mathrm{hr}$ before surgery with either vehicle $(10 \mathrm{~mm}$ sodium phosphate, $\mathrm{pH} 7.4,0.9 \% \mathrm{NaCl}$, and $1 \%$ bovine serum albumin) or BDNF [human recombinant BDNF, expressed in Escherichia coli (gift from Regeneron Pharmaceuticals)] to deliver 1.0 $\mu \mathrm{g} / \mathrm{d} /$ side for $14 \mathrm{~d}$ for the NAc and $2.5 \mu \mathrm{g} / \mathrm{d}$ for $14 \mathrm{~d}$ for the VTA. In a control group, NGF (gift from Genentech, San Francisco, CA) was similarly infused into the VTA at $2.5 \mu \mathrm{g} / \mathrm{d}$ for $14 \mathrm{~d}$. Minipumps were placed in saline solution and incubated at $37^{\circ} \mathrm{C}$ overnight to ensure immediate infusion of solution after placement.

Bilateral L-shaped cannulas for the NAc placements (28 gauge, $9.0 \mathrm{~mm}$ long, bilateral connector $3 \mathrm{~mm}$ apart; model 3220PD, Plastics One) were implanted under Equithesin $(4.5 \mathrm{mg} / \mathrm{kg}$, i.p.) anesthesia. Unilateral cannulas were used for the midline VTA infusions. Standard stereotaxic procedures (David Kopf, Tujunga, CA) were used with aseptic surgical techniques. Coordinates were based on the Paxinos and Watson atlas (1982) with skull flat, i.e., incisor bar at approximately $-3.3 \mathrm{~mm}$. Coordinates for NAc were as follows: anteroposterior (AP), $+1.5 \mathrm{~mm}$ from bregma; mediolateral (ML), $\pm 1.5 \mathrm{~mm}$; and dorsoventral (DV), $-6.7 \mathrm{~mm}$ from dura. For the VTA, they were as follows: AP, $-5.3 \mathrm{~mm}$ from bregma; and DV, $-8.4 \mathrm{~mm}$ from dura. The skull was exposed, and burr holes were drilled on either side of the midline for the NAc; single placements were midline for the VTA. Cannulas were lowered using a mounting holder (model MH-300; Plastic Products).

Stainless steel mounting screws and light curable dental resin were used to achieve permanent cannula implantation and fixation to the skull. Animals were surgically prepared with two osmotic minipumps loaded with BDNF or vehicle solution, which were connected to cannula terminating in the NAc. For the VTA infusions, one osmotic minipump was implanted. Minipumps were placed subcutaneously between the scapulas and attached via plastic tubing (PE 60) to the implanted cannula. At the end of implantation, the head incision was sutured closed. In the CR study, the pumps were removed under light metaphane anesthesia $\sim 1$ month after implantation, and the wound was cleaned. Antibiotic ointment was applied to the wound area.

\section{Drug treatments}

Drug doses, determined from previous studies on sensitization and CR, were as follows. In the intra-NAc BDNF study, an initial challenge dose of $15 \mathrm{mg} / \mathrm{kg}$ cocaine intraperitoneally (cocaine hydrochloride; National Institutes on Drug Abuse, Bethesda, MD) was administered. Cocaine dosage was subsequently lowered to a subthreshold dosage of $5 \mathrm{mg} / \mathrm{kg}$ because of an observed "ceiling effect." This dosage was then given over subsequent days (for review, see Horger et al., 1994; Taylor and Horger, 1999). In two separate replications with intra-NAc BDNF infusions, 7.5 or $10.0 \mathrm{mg} / \mathrm{kg}$ cocaine was administered over days. A dose of $10 \mathrm{mg} / \mathrm{kg}$ cocaine intraperitoneally was administered throughout the CR study (Beninger et al., 1981) and was administered to mice in the sensitization study (Hiroi et al., 1997). In the intra-VTA BDNF study, an initial dose of $15 \mathrm{mg} / \mathrm{kg}$ cocaine intraperitoneally was used. On two subsequent days, $30 \mathrm{mg} / \mathrm{kg}$ cocaine was given and, on the final test day, the dose of cocaine administered was $15 \mathrm{mg} / \mathrm{kg}$. Cocaine was dissolved in sterile $0.9 \%$ sodium chloride, which was used for vehicle control injections.

\section{Apparatus}

Locomotor activity studies. Horizontal locomotor activity was quantified using the automated Omnitech (Columbus, $\mathrm{OH}$ ) Digiscan Micromonitor system equipped with 16 photocells and the same type of cage used to house rats in the colony room. Locomotor activity was collected in 10 min intervals. The activity chambers were plastic cages $(42 \times 21 \times 20$ $\mathrm{cm})$, located inside a sound-attenuated room equipped with a white-noise generator. During activity testing, the room was illuminated with red light only. For the intra-VTA studies, locomotor activity was tested in a circular donut-shaped chamber with a similar computerized photocell arrangement to detect horizontal ambulatory movement. Locomotor activity was also collected over 10 min intervals. For the BDNF knockout mouse study, locomotor activity was determined in an automated system in which the activity chambers were plastic cages $(12 \times 18 \times 33$ $\mathrm{cm}$ ) with 10 pairs of photocell beams dividing the chamber into 11 rectangular fields, as described previously (Hiroi et al., 1997).

$C R$ studies. Four aluminum operant chambers $(12 \times 8 \times 10$ inches $)$ with grid floors were used (ENV-008CT; Med Associates Inc., E. Fairfield, VT). Each chamber was housed in a soundproof outer chamber $(24 \times 24.5 \times 16$ inches $)$ equipped with a white-noise generator and ventilating fan to minimize external noise. A liquid dipper $(0.06 \mathrm{ml}$ cup size) delivered water as the reinforcer into the magazine. Head entries were detected by a photocell above the reinforcer receptacle. Above this magazine was a $2.5 \mathrm{~W}, 24 \mathrm{~V}$ light. Two removable levers were situated equidistant from, but on the same wall as, the magazine with a stimulus light above the magazine. The chamber was illuminated by a white light on the back wall of the chamber. A Sonalert tone $(10 \mathrm{kHz})$ generator (Med Associates, Inc.), which could emit a $65 \mathrm{~dB}$ tone above background noise, was mounted above the magazine. A personal computer with a Med Associates Inc. interface controlled the boxes.

\section{Statistical analyses}

Locomotor activity was analyzed by a two-way repeated measures ANOVA, followed by one-way ANOVA to determine whether there were differences between the groups before and after cocaine-saline administration. Post hoc comparisons using the Scheffe method were used to determine differences between the groups at each of the $10 \mathrm{~min}$ time points before and after the challenge injection. Activity scores for the mice were assessed similarly as locomotor activity scores by ANOVA with post hoc comparisons between the groups.

CR data were analyzed by ANOVA with a general design of groups $($ BDNF or vehicle $) \times$ drug $\times$ lever/measure. Data were then analyzed by one-way ANOVA to determine differences between the groups on the CR and no CR (NCR) levers separately under the saline or cocaine tests (Winer, 1974). Post hoc comparisons were conducted using the Scheffe method to determine differences between the levers for animals in the groups after the saline or cocaine tests.

\section{Histological analyses}

Determination of the location of the infusion cannula placements was assessed at the completion of the experiments. Brains were removed by decapitation and cut into coronal sections on ice. Sections were visually inspected by an experimenter unaware of the treatment group, and infusion cannula placements were examined to verify that their location was within the NAc or VTA as intended. 


\begin{tabular}{|c|c|c|c|}
\hline Event & Description & $\mathrm{d} /$ time & Schedule/procedure \\
\hline \multicolumn{4}{|c|}{ Locomotor sensitization: } \\
\hline Phase 1 & Habituation & $2-4$ & Locomotor testing $(2 \mathrm{hr})$ \\
\hline Phase 2 & Surgery & & Intra-NAc or intra-VTA osmotic pump \\
\hline Phase 3 & Recovery & 4 & Home cage \\
\hline Phase 4 & Saline & 2 & Locomotor testing ( 2 hours) \\
\hline Phase 5 & Testing & daily & $\begin{array}{l}\text { Cocaine (NAc } 15-5,7.5 \text {, and } 10 \mathrm{mg} / \mathrm{kg} \text {; and } \\
\text { VTA, } 15,30,30 \text {, and } 15 \mathrm{mg} / \mathrm{kg} \text { ) }\end{array}$ \\
\hline \multicolumn{4}{|c|}{ Conditioned reinforcement } \\
\hline Phase 1 & Pretraining & 2 & FI $15 \mathrm{sec}$ CS-UCS \\
\hline Phase 2 & Training & 14 & RI $30 \mathrm{sec}$ CS-UCS \\
\hline Phase 3 & Surgery & & Intra-NAc osmotic pump \\
\hline Phase 4 & Recovery & 7 & Home cage \\
\hline Phase 5 & Testing & $1,2,3$, and 5 weeks & $\mathrm{CR}$ and NCR levers; saline or cocaine $10 \mathrm{mg} / \mathrm{kg}$ \\
\hline
\end{tabular}

\section{Experiment 1: effects of intra-NAc or VTA BDNF on cocaine- induced locomotor activity}

Intra-NAc BDNF. The general experimental design is presented in Table 1. All animals were habituated to the locomotor test apparatus before the start of the experiment. Four sessions were given. Animals were placed in the apparatus for $1 \mathrm{hr}$. An intraperitoneal saline injection was subsequently given, and they were placed back in the apparatus for an additional $1 \mathrm{hr}$ time period. Surgery was performed to implant osmotic minipumps that were loaded with BDNF or phosphate buffer (vehicle control). Four days after surgery, the rats were again habituated to the locomotor test environment for $2 \mathrm{hr}$ (as described above). Habituation sessions were given over 2 consecutive days, and saline injections were given intraperitoneally $1 \mathrm{hr}$ after the start of the session. This served to assess the baseline activity in the test environment in response to a mild stressor. On the first drug test day, animals were placed in the locomotor test apparatus for $1 \mathrm{hr}$ before receiving a cocaine injection $(15 \mathrm{mg} / \mathrm{kg}$, i.p.). Locomotor activity was monitored for $1 \mathrm{hr}$ after cocaine administration. Subsequently, drug test sessions were conducted every day for a total of seven test sessions. On the second day of drug testing, the dose was reduced to $5 \mathrm{mg} / \mathrm{kg}$ in an attempt to avoid a ceiling effect, because near maximal rates of locomotor activity were observed in BDNFinf used animals after $15 \mathrm{mg} / \mathrm{kg}$ cocaine. Animals were killed $24 \mathrm{hr}$ after the last drug test session.

The effects of 7.5 and $10.0 \mathrm{mg} / \mathrm{kg}$ cocaine were similarly studied in separate groups of intra-NAc-inf used animals. Doses of either 7.5 or 10.0 $\mathrm{mg} / \mathrm{kg}$ cocaine were given according to the same schedule and experimental design as detailed above.

Intra-VTA BDNF. The effects of cocaine were also studied in separate groups of rats that had undergone surgery to infuse BDNF into the VTA. Here, the design differed as follows. Two days after surgery to implant intra-VTA cannula filled with BDNF or vehicle, animals began habituation sessions. Animals were placed in the test chambers for 30 min over 4 consecutive days, totaling $2 \mathrm{hr}$. Animals were given saline injections before these sessions to habituate them to the test environment. Stable baselines were established. On the first drug exposure day, animals were given $15 \mathrm{mg} / \mathrm{kg}$ cocaine intraperitoneally immediately before the session, on the second and third session they were given 30 $\mathrm{mg} / \mathrm{kg}$ cocaine intraperitoneally, and on the final day they received the 15 $\mathrm{mg} / \mathrm{kg}$ intraperitoneal dose. Locomotor activation on this test day were compared with the effects of the drug on the first test day. Generally, in this paradigm, naive animals show a 100-200\% increase in locomotor activity after cocaine (Kalivas and Duffy, 1993).

We also infused NGF into the VTA using the above procedures as a control to determine whether the effects were selective to the specific neurotrophic factor. Given that NGF utilizes the TrkA receptor (Kaplan et al., 1991) that and there are no TrkA receptors in the VTA, NGF inf usions into the VTA were predicted to have no effects on spontaneous or cocaine-induced locomotor activation. This condition also served to provide some evidence of regional selectivity because diffusion of NGF to other sites could potentially influence behavior.

\section{Experiment 2: effects of intra-NAc BDNF on $C R$}

The general experimental procedure for these studies consisted of five phases, as depicted in Table 1. We used a CR procedure that has been published previously in detail with minor modifications (Taylor et al., 1984, 1986; Taylor and Horger, 1999). It has been termed the "acquisition of the new response" procedure because animals are not trained to lever press before the test phase; as a result, the lever-pressing response is reinforced by the presentation of the conditioned stimulus (CS), thus acting as a CR (Mackintosh, 1974; Robbins, 1978).

Pretraining. For the first 20 min pretraining session, water-deprived rats were habituated to the operant chamber with both levers absent; presentations of water reward as the unconditioned stimulus (UCS) were given every $15 \mathrm{sec}$, and the dipper was elevated for $5 \mathrm{sec}$. Presentation of the water was immediately preceded by a combination CS: a $3 \mathrm{sec}$ illumination of the tray light plus tone, house-light offset (and characteristic sound of the dipper elevating). The house-light offset served to increase the salience of the visual component of the compound stimulus as in our previous study (Taylor et al., 1986). In a second 20 min session, animals were discouraged from entering the magazine for water reward prematurely by introducing a time-out $3 \mathrm{sec}$ delay in subsequent UCS presentations. The use of this delay ensures that a $3 \mathrm{sec}$ period with no magazine entries elapsed before the CS onset and ensures a more explicit association of the CS with the UCS. There were 30 CS-UCS presentations in a fixed interval (Table 1, FI) schedule in the pretraining sessions. All sessions began with illumination of the house light.

Training. Training occurred daily with one session per day. The CSUCS pairing were presented according to a random interval (RI) $30 \mathrm{sec}$ schedule with the $3 \mathrm{sec}$ "penalty" delay period in place. There were 30 CS-UCS presentations during each of 15 sessions. Head entries during CS-UCS and RI periods were used to assess discriminative approach (Burns et al., 1994). As animals learn the CS-UCS association, they make fewer magazine entries and spend less time with their heads in the magazine at times other than during the CS-UCS presentation. This acquisition curve can thus be used to confirm that all animals are learning.

Testing. Levers were present in the chamber for the first time. Cocaine (10 $\mathrm{mg} / \mathrm{kg}$, i.p.) and saline injections were given in a counterbalanced order such that animals were tested twice each week, preceded by either a saline injection or a cocaine injection. Injections were given $5 \mathrm{~min}$ before placement in the operant chamber. Responding the CR lever resulted in presentation of the stimuli associated with water, and responding on the NCR lever had no programmed consequences. Sessions lasted $30 \mathrm{~min}$ from the first response on the CR lever. The CR and NCR levers were randomly assigned but remained constant throughout the experiment. Responding on the CR lever resulted in appropriate stimulus presentation for $3 \mathrm{sec}, 50 \%$ of the time. Eight test sessions were given (four saline, four cocaine). There were at least $2 \mathrm{~d}$ between saline and cocaine injections and 1 week between these test sessions. Note that $2 \mathrm{~d}$ before the third test session, the pumps were removed under anesthesia (see above). 


\section{Nucleus Accumbens (NAc)}

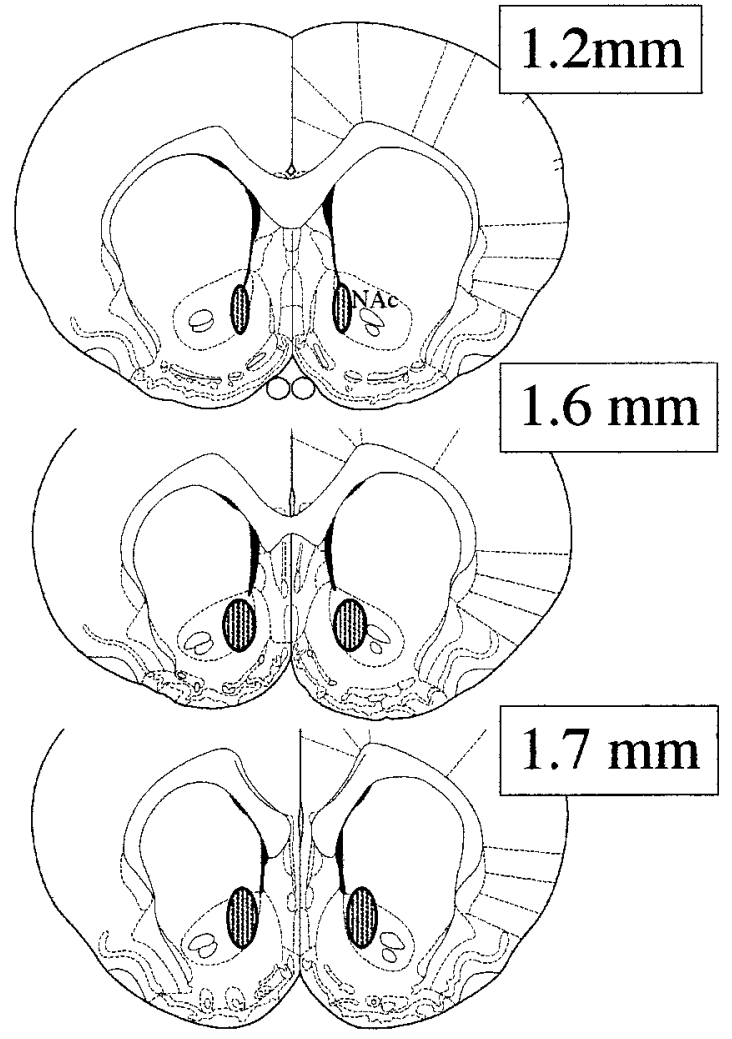

Ventral Tegmental Area (VTA)

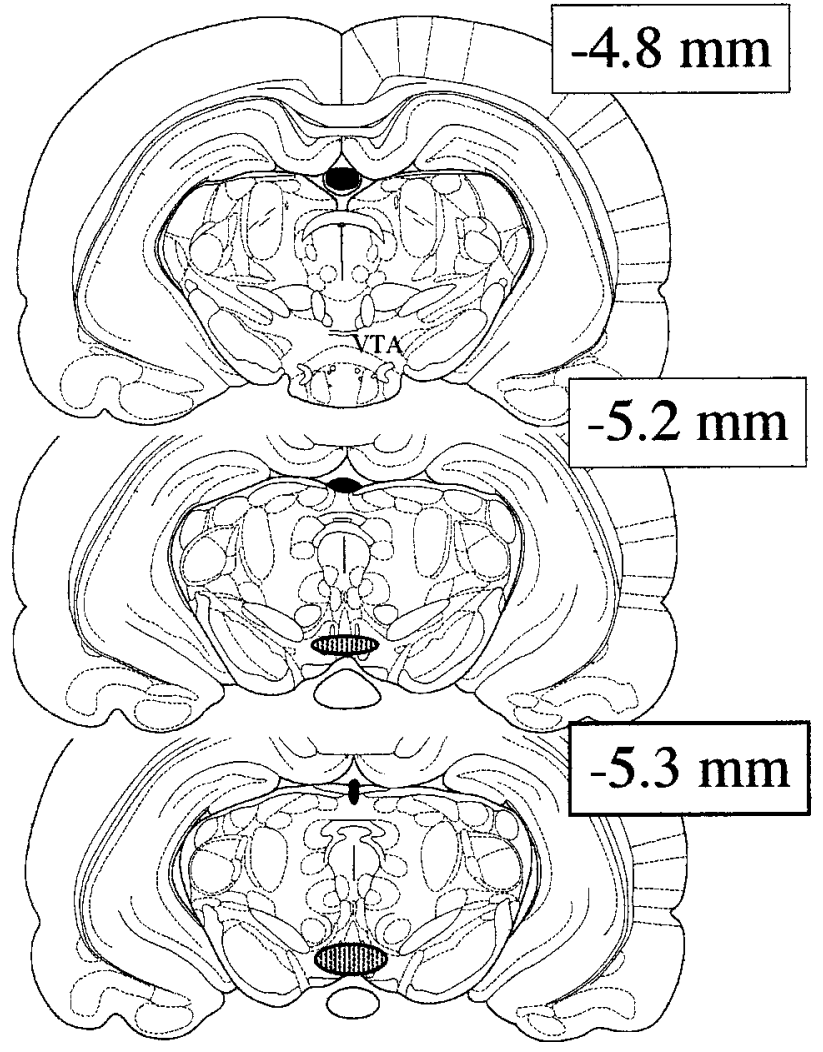

Figure 1. The locations of the cannula placements within the NAc and VTA are illustrated in diagrams of coronal sections reproduced from the atlas of Paxinos and Watson (1997). The region of the NAc (left) and VTA (right) where infusion tips were located are shown as hatched regions.

Experiment 3: development of locomotor sensitization after 10 $\mathrm{mg} / \mathrm{kg}$ cocaine in BDNF knock-out mice

Mice were tested at the same time each day by an experimenter who did not know whether the animals were heterozygous BDNF knock-out $(+/-; n=5)$ or wild-type $(+/+; n=4)$ mice. Heterozygous mice were used because homozygous BDNF knock-out mice are not viable. Moreover, it is known that the heterozygous mice show reduced levels of BDNF in brain (Vaidya et al., 1999). For the first $3 \mathrm{~d}(\mathrm{H} 1-\mathrm{H} 3)$, they were habituated to the chambers immediately after an intraperitoneal saline injection. Horizontal activity was then measured for $10 \mathrm{~min}$. Baseline activity counts were calculated as the average of the second and third habituation days. On days 4-9, they were tested after an intraperitoneal injection of $10 \mathrm{mg} / \mathrm{kg}$ cocaine (C1-C6), and activity was measured for 10 min. Locomotor activity predominates in this schedule (Hiroi et al., 1997) and, although not formally measured, focused stereotypy was not observed in the wild-type or mutant mice.

\section{RESULTS}

\section{Histological analysis}

Histological analyses revealed that all animals had evidence of cannula placements and infusion tracts that were within the NAc or VTA, as depicted in Figure 1. The cannula placements within the NAc were localized medial to the anterior commissure in the posteromedial region of the NAc. The infusion sites ranged approximately between 1.2 and $0.8 \mathrm{~mm} \mathrm{ML}$ and between 1.2 and $1.7 \mathrm{~mm}$ AP and thus were located primarily within the lateral shell region of the NAc. However, diffusion of BDNF to core regions cannot be ruled out, because infusion sites were close to the shell-core border. Tracts in the VTA were also restricted to this region, ranging from -4.8 to $-5.3 \mathrm{~mm}$ AP. There was no apparent relationship between infusion site and behavioral response. Damage to the overlying regions appeared to be minimal.

\section{Experiment 1: effects of intra-NAc or intra-VTA BDNF on cocaine-induced locomotor activity}

Effects of BDNF into the NAc or VTA on weight

In the sensitization study, weight was monitored daily. No significant overall differences were noted between control and BDNF animals over time $\left(F_{(1,10)}=1.38 ; p<1.0\right)$ Both control and most of the BDNF animals showed a significant increase in weight gain over time $\left(F_{(1,10)}=54.15 ; p<0.01\right)$. However, two BDNF animals were consistently found to be $25 \%$ below weight immediately after surgery when compared with control and healthy BDNF animals. A significant trend for weight loss in these two BDNF animals compared with weight gain in control and the other BDNF animals continued over time $\left(F_{(1,10)}=6.10 ; p<\right.$ $0.001)$; these animals were not tested and were killed for humane reasons $9 \mathrm{~d}$ after surgery. After intra-VTA BDNF infusions, weight gain was observed to increase $\sim 8 \%$ over the $10 \mathrm{~d}$ of the experiment, whereas vehicle-infused animals showed a greater increase $(24 \%)$ in weight gain over the experimental period (Berhow et al., 1995).

\section{Effects of BDNF into the NAc on stress-induced locomotor activity}

Saline injections $(0.3 \mathrm{ml}$, i.p.) increased locomotor activity on days 5 and 6 (after surgery) to a greater extent in the BDNFinfused compared with the vehicle-infused group (Fig. 2). In 


\section{Intra-NAc BDNF infusions}

Figure 2. Effects of intra-NAc BDNF infusions on locomotor behavior in response to saline injections. Saline injections $(0.3 \mathrm{ml}$, i.p.) significantly increased locomotor activity for $10 \mathrm{~min}$ after the injection $(* p<0.05)$ on days 5 and 6 (after surgery) in the BDNF-infused compared with the vehicle-infused group. In contrast, there were no differences before the injections on either day. Data are expressed as the mean \pm SEM number of photocell disruptions over the 30 min test period.
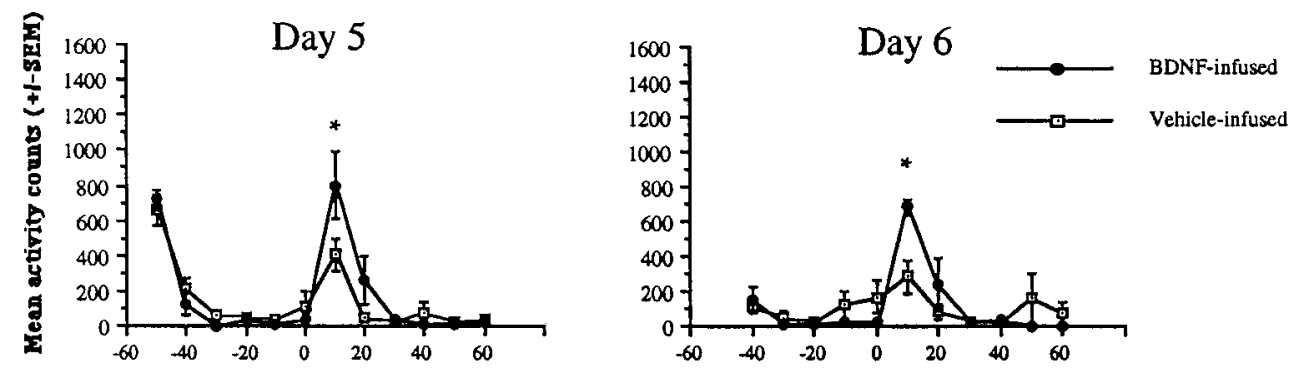

\section{Intra-NAc BDNF infusions}

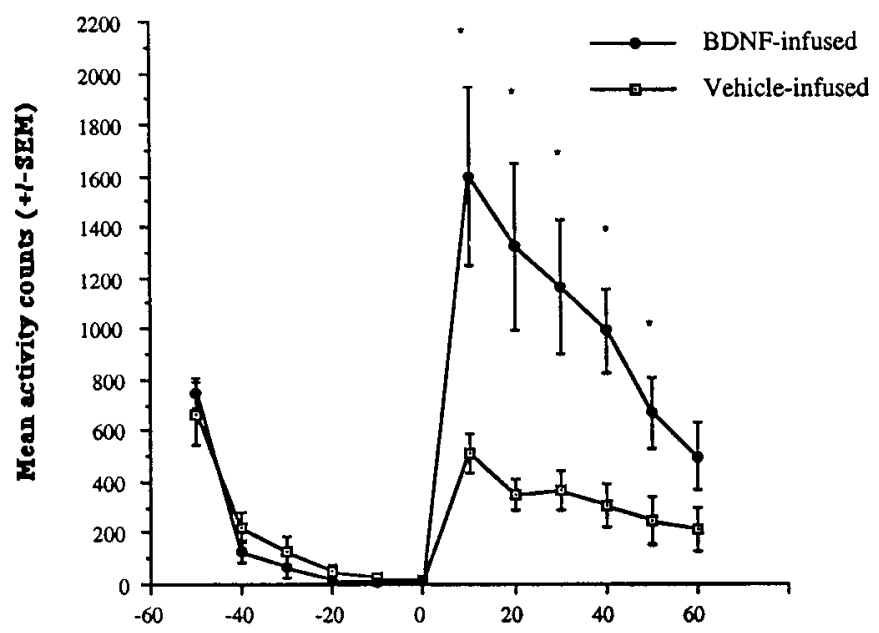

Time ( $\mathrm{min})$ before and after cocaine $(15 \mathrm{mg} / \mathrm{kg})$ injection

Figure 3. Effects of intra-NAc BDNF infusions after cocaine challenge. Cocaine injection $(15 \mathrm{mg} / \mathrm{kg}$ ) given on day 7 (after surgery) resulted in locomotor activity rates that were markedly increased in the BDNFinfused compared with the vehicle-infused group; locomotor activity in the BDNF group was significantly higher at 10, 20,30, 40, and 50 min after the cocaine injection $\left(F_{(1,10)}=13.04,11.93,11.43,16.95\right.$, and 7.02 , respectively; $\left.{ }^{*} p<0.01\right)$. No differences before the injection were found. Data are expressed as the mean \pm SEM number of photocell disruptions over the 30 min test period.

contrast, there were no differences before the injections on either day, as indicated by a significant interaction between group $\times$ time $\left(F_{(1,10)}=2.28 ; p<0.02 ; F_{(1,10)}=2.38 ; p<0.02\right.$, on days 5 and 6 , respectively). The significant difference between control and BDNF animals was found at $10 \mathrm{~min}$ after saline administration on both days.

\section{Effects of BDNF into the NAc on locomotor activity}

There was a significant difference in locomotor activity and in the development of sensitization between BDNF-infused and vehicle-infused animals. After the $15 \mathrm{mg} / \mathrm{kg}$ cocaine injection, there was a significant increase in locomotor activity in BDNFinfused compared with vehicle-infused animals. A significant interaction between time $\times$ group was found, indicating differences after, but not before, the cocaine injections (day 7 , $F_{(1,110)}=9.19 ; p<0.001$ ) (Figure 3 ). BDNF infusions into the NAc resulted in cocaine-induced locomotor activity rates that were triple those seen in control animals for the 10 min immediately after the cocaine injection. Further, the significant increase in BDNF-infused animals compared with vehicle-infused animals continued to be evident at 20,30, 40, and 50, but not 60 , min after the cocaine injection. No differences between the groups were observed before the cocaine challenge. A significant enhancement of the locomotor activating effects of cocaine was therefore found in the BDNF-infused animals.

At $5 \mathrm{mg} / \mathrm{kg}$ cocaine, a subthreshold dose for the induction of sensitization, BDNF-infused animals developed sensitization over time as a result of the intra-NAc BDNF inf usions. Vehicleinf used animals did not show sensitization (Fig. 4). On day 8 (the second cocaine injection), there were no differences between vehicle-inf used and BDNF-infused animals at any time before or after the cocaine injections, as indicated by a lack of significant interaction between group $\times$ time $\left(F_{(1,110)}=0.39 ; p<0.1\right)$. However, by day 9 , the BDNF-inf used animals began to show an enhanced response to the locomotor-activating effects of cocaine, as indicated by a group $\times$ time interaction $\left(F_{(1,110)}=3.53 ; p<\right.$ $0.001)$. These effects continued on days 10,11 , and $12\left(F_{(1,110)}=\right.$ $2.89,4.91$, and 2.69, respectively; $p<0.05$ ). Sensitization did not develop in vehicle-infused animals at this subthreshold dose of 5 $\mathrm{mg} / \mathrm{kg}$ cocaine.

Together, these data indicate that intra-NAc BDNF-infused animals showed an enhanced response to the locomotoractivating effects of $15 \mathrm{mg} / \mathrm{kg}$ cocaine and showed locomotor sensitization after repeated injections of $5 \mathrm{mg} / \mathrm{kg}$ cocaine, effects not observed in vehicle-infused animals.

\section{Effects of BDNF into the NAc on locomotor activity after 7.5 or $10.0 \mathrm{mg} / \mathrm{kg}$ cocaine}

Repeated administration of cocaine at either dose of 7.5 or 10.0 $\mathrm{mg} / \mathrm{kg}$ resulted in a more rapid development of sensitization over time as a result of intra-NAc BDNF infusions compared with vehicle infusions, as shown in Figures 5 and 6 . The pattern of results was slightly different from that described above and was dose-related; $10 \mathrm{mg} / \mathrm{kg}$ cocaine resulted in a more robust sensitization than $7.5 \mathrm{mg} / \mathrm{kg}$ cocaine, and vehicle-inf used animals became sensitized notably at the $10 \mathrm{mg} / \mathrm{kg}$ dose of cocaine.

No differences between the groups were observed after the first injection (day 7) of $7.5 \mathrm{mg} / \mathrm{kg}$ cocaine (Fig. 5). On the second day (day 8), cocaine induced markedly higher levels of locomotor activity in the BDNF-infused compared with the vehicle-inf used animals; no differences in activity were observed before the injection of cocaine $\left(F_{(11,66)}=3.55 ; p<0.01\right)$. Activity rates were elevated in the BDNF-inf used compared with the vehicle-inf used animals for $30 \mathrm{~min}$ after the injection. Although locomotor activ- 


\section{Intra-NAc BDNF infusions}
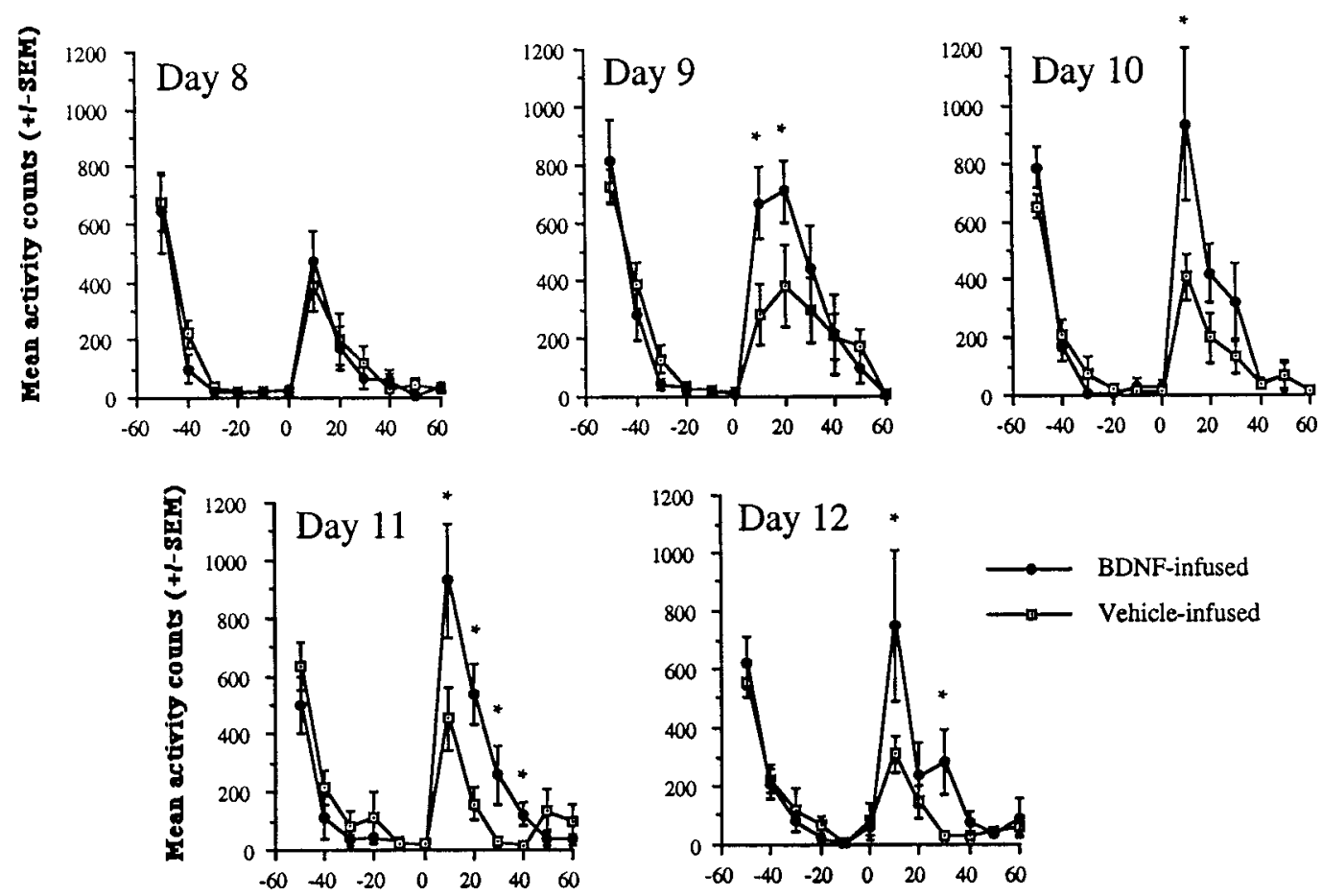

Time $(\mathrm{min})$ before and after cocaine $(5 \mathrm{mg} / \mathrm{kg})$ injection

Figure 4. Effects of intra-NAc BDNF infusions on locomotor activation after a low dose of cocaine (5 mg/ $/ \mathrm{kg})$. At $5 \mathrm{mg} / \mathrm{kg}$ cocaine, a subthreshold sensitization dose, animals infused with BDNF developed sensitization, whereas vehicle-inf used animals did not show sensitization. On day 8 , there were no differences, whereas on days 9-12 there were significant differences between the groups at each of the time points shown $\left({ }^{*} p<0.05\right)$. Differences were as follows: day 9 BDNF-inf used animals had increased locomotor rates at 10 and 20 min after cocaine $\left(F_{(1,10)}=6.33\right.$ and 5.97, respectively; $\left.p<0.05\right)$; day 10 increases were found at $10 \mathrm{~min}$ after cocaine $\left(F_{(1,10)}=5.21 ; p<0.05\right)$; on day 11, a significant difference between vehicle-infused and BDNF-infused animals was observed at $10,20,30$, and $40 \mathrm{~min}$ after the cocaine injection $\left(F_{(1,10)}=5.33,12.03,7.10\right.$, and 8.94 , respectively; $\left.p<0.05\right)$; on day 12, there continued to be differences between the BDNF-inf used and vehicle-infused animals; significant differences between the groups were found at $10 \mathrm{~min}$ after the cocaine injection and a trend at $30 \mathrm{~min}\left(F_{(1,10)}=7.71\right.$ and 3.76, respectively; $p<0.05$ and 0.08 , respectively). There were no differences between the groups before the cocaine injections. Data are expressed as the mean \pm SEM number of photocell disruptions over the 30 min test period.

ity remained generally increased in BDNF-infused animals over the repeated days of the cocaine injections, vehicle-inf used animals also showed some increases in locomotor activity over time and, thus, there were only significant differences between the groups on day 10 [group $\times$ time interaction $\left(F_{(11,66)}=2.69 ; p<\right.$ $0.01)]$. Differences between the groups were not observed before the cocaine injections. In the vehicle-inf used animals, this dose of cocaine produced sensitization, but the effects were less robust and more variable than the effects in the BDNF-infused group. This dose of $7.5 \mathrm{mg} / \mathrm{kg}$ cocaine is known to have somewhat variable effects in control animals. Nevertheless, in BDNFinfused animals, $7.5 \mathrm{mg} / \mathrm{kg}$ cocaine resulted in rapid sensitization. Similar effects were observed with $10 \mathrm{mg} / \mathrm{kg}$ cocaine, but the magnitude of the locomotor sensitization was greater.

As depicted in Figure 6, intra-NAc BDNF-infused animals compared with vehicle-inf used animals showed an increase in the development of sensitization to $10 \mathrm{mg} / \mathrm{kg}$ cocaine; also, there appeared to be some enhancement of the initial locomotoractivating effects of cocaine similar to that observed with the 15 $\mathrm{mg} / \mathrm{kg}$ dose of cocaine in these intra-NAc BDNF-infused animals. After the first dose of cocaine (day 7), there were already differences between the groups, which continued to be observed over the next two injection days (days 7,8 , and 9 , group $\times$ time interaction, $F_{(11,66)}=7.87,8.44$, and 3.81, respectively; $\left.p<0.01\right)$. By day 10 , there was only a trend $\left(F_{(11,66)}=1.68 ; p<0.07\right)$. Thereafter, the vehicle-infused animals showed similar increases in activity as the BDNF-inf used animals, indicating sensitization, except on day 13 when activity rates in the vehicle-infused group were somewhat low compared with previous and subsequent sessions $\left(F_{(11,66)}=4.13 ; p<0.01\right)$. Again, there were no significant differences between the groups before cocaine injections on any day of testing. In contrast to the effects obtained with $7.5 \mathrm{mg} / \mathrm{kg}$, at the $10 \mathrm{mg} / \mathrm{kg}$ dose, BDNF-infused animals showed greater increases in locomotor activity over days, and the vehicle-inf used animals showed a more robust sensitization at this higher dose.

\section{Effects of BDNF or NGF into the VTA on locomotor activity}

Animals that received a chronic intra-VTA BDNF regimen showed higher levels of activity in response to cocaine (Fig. 7). On the first exposure to cocaine, intra-VTA BDNF animals had a $268 \%$ increase in locomotor activity compared with vehicleinfused animals receiving the same dose of cocaine (Fig. 7, left). BDNF-inf used animals showed a significant increase in locomo- 


\section{Intra-NAc BDNF infusions}
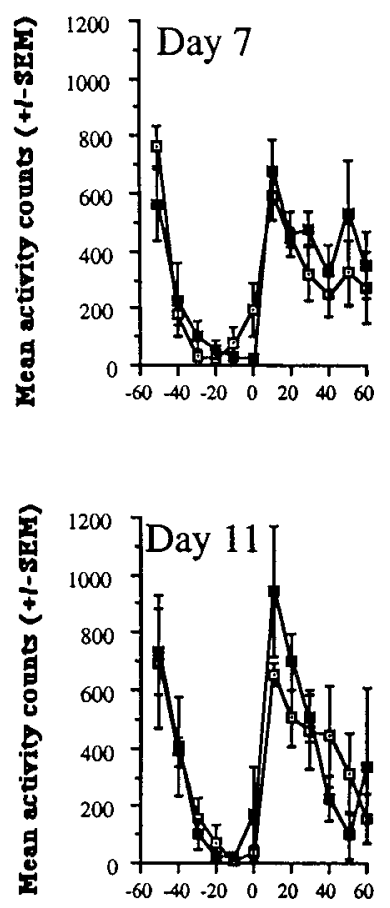
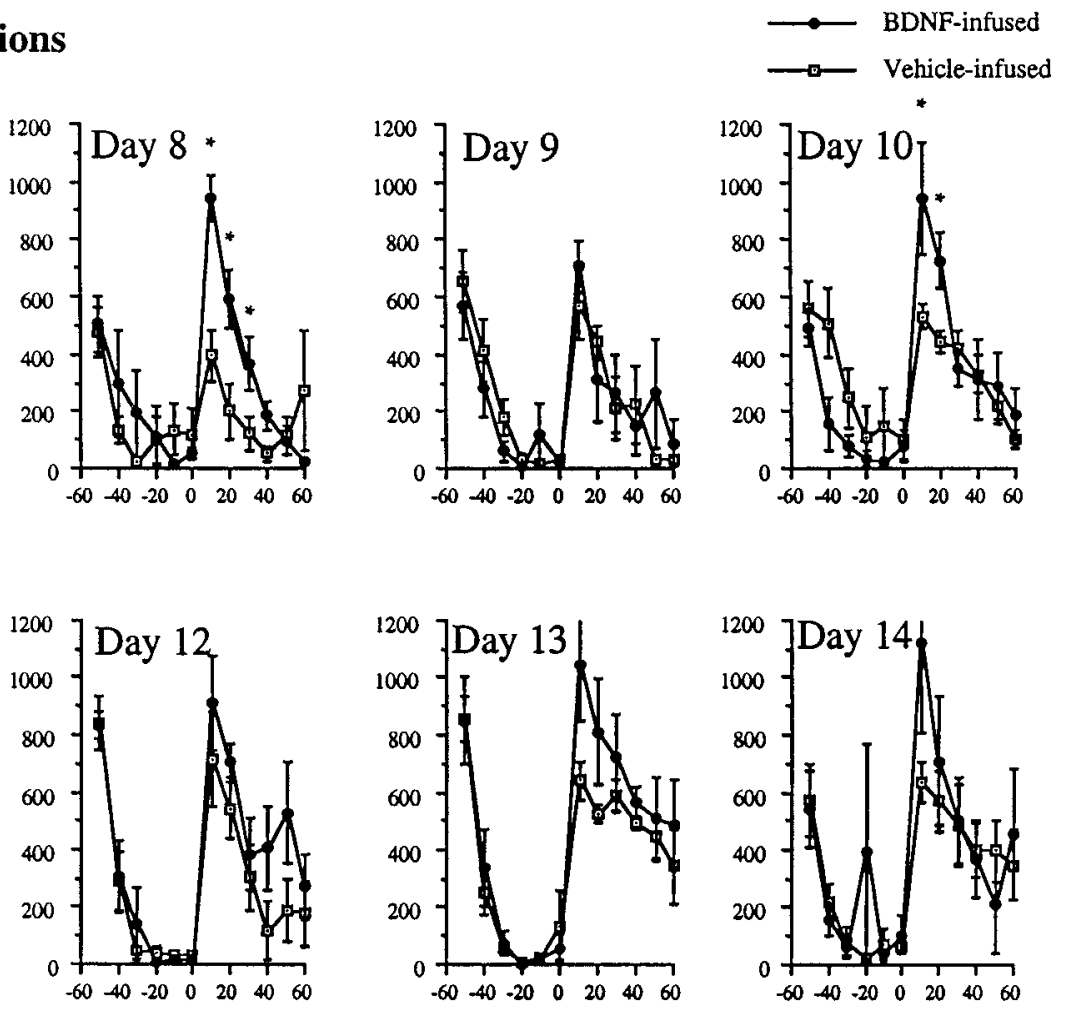

Time $(\mathrm{min})$ before and after cocaine $(7.5 \mathrm{mg} / \mathrm{kg})$ injection

Figure 5. Effects of intra-NAc BDNF infusions on locomotor activation after $7.5 \mathrm{mg} / \mathrm{kg}$ cocaine. At $7.5 \mathrm{mg} / \mathrm{kg}$ cocaine, a near threshold sensitization dose, animals infused with BDNF showed a more rapid development of sensitization. Vehicle-infused animals also showed some evidence of sensitization. Cocaine injections $(7.5 \mathrm{mg} / \mathrm{kg}$ ) given on days 8 and 10 (after surgery) resulted in activity rates that were markedly increased in BDNF-inf used compared with the vehicle-inf used animals. Significant differences $(* p<0.05)$ at time points after cocaine injections were as follows: day 8 at 10, 20, and $30 \mathrm{~min}, F_{(1,6)}=16.25,12.01$, and 10.67, respectively; day 10 at 10 and $20 \mathrm{~min}, F_{(1,6)}=6.41$ and 7.41, respectively. No differences between the groups were found before the cocaine injections. Data are expressed as the mean \pm SEM number of photocell disruptions over the 30 min test period.

tor activity after $15 \mathrm{mg} / \mathrm{kg}$ cocaine compared with vehicle-inf used animals, on both the first test day (C1) and the final test day (C-TEST). However, there were no changes in locomotor activity in response to cocaine over these test days in BDNF-infused animals (i.e., C1 vs C-TEST). The vehicle-infused animals did show a rapid and robust locomotor sensitization over the test sessions ( $\mathrm{C} 1$ and C-TEST). Nevertheless, the failure of the BDNF-infused animals to show a progressive increase over time, indicative of sensitization, was probably caused by ceiling effects, as suggested by the intra-NAc BDNF studies with moderate to high (10-15 mg/ $\mathrm{kg}$ ) doses of cocaine in which an initial enhancement of the locomotor-activating effects of cocaine was also observed. There were no significant differences between the groups during baseline (H4); however, BDNF-infused animals showed somewhat higher rates. In contrast to the potent locomotor-activating effects of cocaine after intra-VTA BDNF infusions, intra-VTA infusions of NGF did not augment the locomotor response to cocaine; intra-VTA NGF infusions produced comparable rates of activity with vehicle-infused animals after cocaine (Fig. 7, right). Animals with intra-VTA infusions of NGF, like both groups of vehicle-inf used animals (Fig. 7), nonetheless did show sensitization to cocaine over time. The lack of effect of NGF is consistent with the lack of biochemical effects and the absence of its TrkA receptors in this brain region (Berhow et al., 1995).

\section{Experiment 2: effects of intra-NAc BDNF on responding for $\mathbf{C R}$}

In the $\mathrm{CR}$ paradigm, as in the previous paradigms, no differences were observed in weight gain between intra-NAc BDNF-inf used and vehicle-inf used animals over time.

\section{Effects of BDNF in the NAc on responding for $C R$}

Enhanced responding for CR was found after intra-NAc BDNF infusions, as shown in Figure 8 (group $\times$ lever interaction, $\left.F_{(7,42)}=11.7 ; p<0.001\right)$. Intra-NAc BDNF enhanced responding on the CR lever compared with animals given intra-NAc vehicle after a saline challenge test. After a cocaine $(10 \mathrm{mg} / \mathrm{kg}$, i.p.) challenge, animals given chronic intra-NAc BDNF showed an even greater potentiated responding on the CR lever compared with intra-NAc vehicle-infused animals. Intra-BDNF infusions also produced significantly more CR lever responses after cocaine compared with saline injections $\left(F_{(1,6)}=10.37 ; p<0.01\right)$. Responding on the control lever (NCR) was lower than on the CR lever under all conditions.

BDNF- and vehicle-infused animals were repeatedly tested with saline and cocaine injections, as shown in Figure 9. Note that challenge days 1 and 2 occurred when BDNF was being inf used, challenge day 3 occurred the week after BDNF inf usions ceased, and day 4 occurred 2 weeks later. After the first saline injection (sal1), there were differences between the two groups on the two 

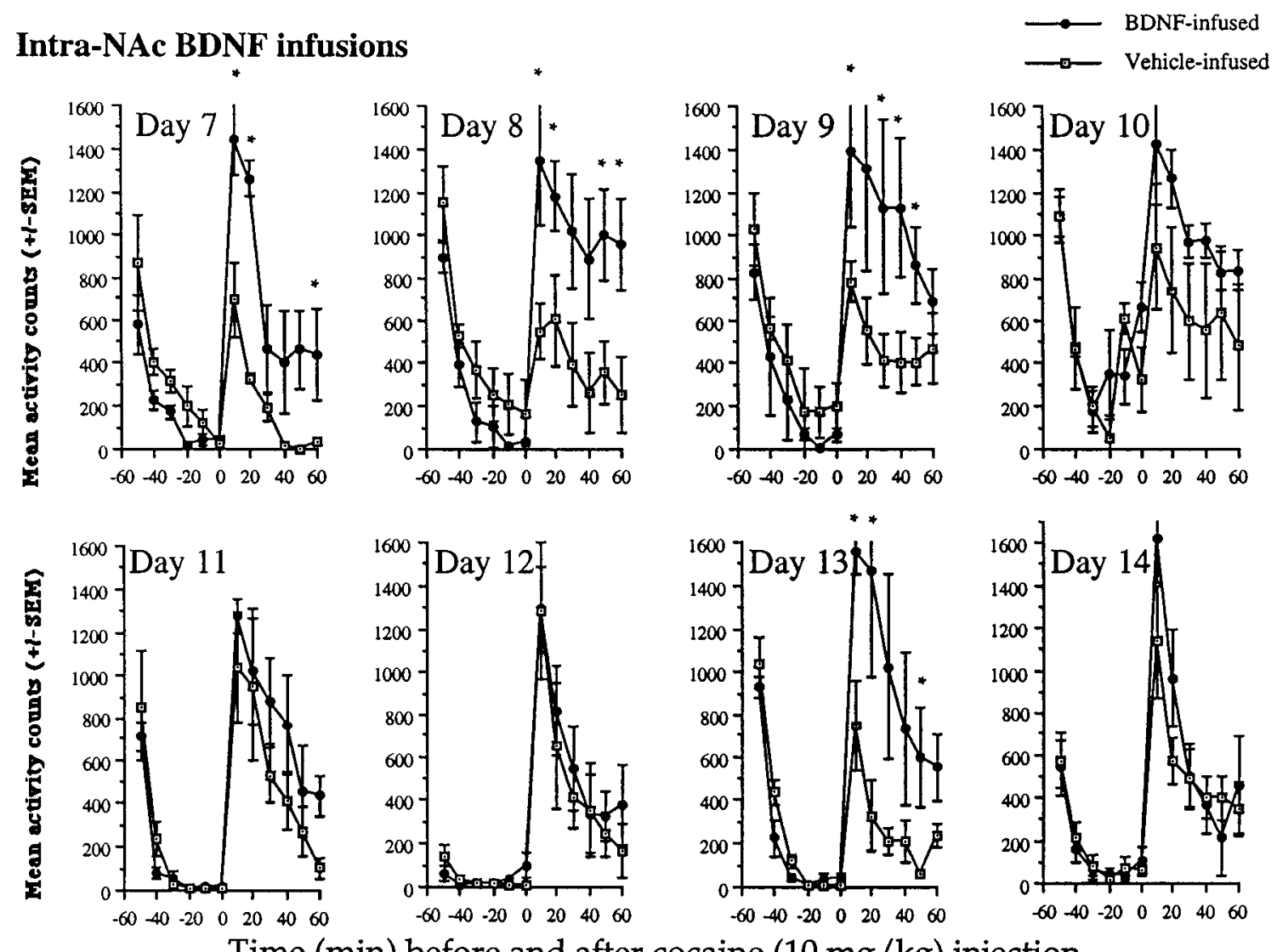

Time $(\mathrm{min})$ before and after cocaine $(10 \mathrm{mg} / \mathrm{kg})$ injection

Figure 6. Effects of intra-NAc BDNF inf usions on locomotor activation after $10 \mathrm{mg} / \mathrm{kg}$ cocaine. BDNF-inf used animals showed higher activity rates than vehicle-inf used animals after repeated cocaine injections (days 7-9). By day 10, the vehicle-inf used animals were similar to BDNF-inf used animals because they had become sensitized to this moderate dose of cocaine. No further differences between the groups were observed over subsequent days, except on day 13 when vehicle-infused animals showed lower activity rates (see Results). Significant differences $\left({ }^{*} p<0.05\right)$ at time points after cocaine injections were as follows: day 7 at 10,20 , and $50 \mathrm{~min}, F_{(1,6)}=15.35,120.81$, and 6.35 , respectively; day 8 at $10,20,50$, and $60 \mathrm{~min}, F_{(1,6)}=6.03,7.41$, 6.11, and 6.47, respectively; day 9 at $10,30,40$, and $50 \mathrm{~min}, F_{(1,6)}=6.19,6.67,6.40$, and 6.66, respectively; day 13 at 10,20 , and $50 \mathrm{~min} F_{(1,6)}=11.35$, 5.82 , and 6.24, respectively. No differences between the groups were found before the cocaine injections. Data are expressed as the mean \pm SEM number of photocell disruptions over the 30 min test period.

levers $\left(F_{(1,6)}=8.21 ; p<0.02\right)$; CR lever presses were increased in the BDNF group compared with the vehicle group, but there were no differences between the groups for NCR lever presses. After the second saline injection, differences between the groups on the two levers were also found $\left(\operatorname{sal} 2, F_{(1,6)}=6.62 ; p<0.05\right)$, and there was a trend for a selective CR increases in the BDNF group on sal2. After the other saline (sal3 and sal4) injections, only preferences for the CR lever over the NCR were found $\left(F_{(1,6)}=17.32\right.$ and 16.77 , respectively; $\left.p<0.01\right)$.

BDNF-inf used animals showed enhanced responding after repeated testing with injections of $10 \mathrm{mg} / \mathrm{kg}$ cocaine (group $\times$ days, $\left.F_{(7,42)}=8.45 ; p<0.01\right)$, as shown in Figure 9. There were differences in responding on the levers in the BDNF-infused subjects after cocaine injections on $\operatorname{coc} 1, \operatorname{coc} 2$, and $\operatorname{coc} 4\left(F_{(1,6)}=\right.$ $22.03,13.29$, and 14.22, respectively; $p<0.01$ ), with selective increases on the CR lever in the BDNF-infused compared with the vehicle-infused group (Fig. 9). After the third cocaine injection ( $\operatorname{coc} 3)$, the BDNF-inf used subjects tended to respond more on the CR lever than vehicle-infused subjects, but this difference did not reach statistical significance. Because the osmotic pumps had been removed under anesthetic a few days before this test day, this event may have resulted in lower response rates. Moreover, there was a significant main effect of group for the CR lever responses (test days coc1-coc4, $F_{(3,18)}=19.02 ; p<0.01$ ), but no main effect of day or interaction (group $\times$ day), confirming that BDNF-inf used subjects responded more on the CR lever than did vehicle-inf used subjects. Thus, in BDNF-infused subjects, the number of responses on the CR lever was markedly increased compared with the NCR lever, and notably, cocaine challenges produced persistent enhanced responding for the CR lever. No differences in responding on the NCR lever were observed over any of the saline or cocaine test days for the groups.

\section{Experiment 3: development of locomotor sensitization in BDNF knock-out mice}

Figure 10 shows the development of sensitization after repeated injections with $10 \mathrm{mg} / \mathrm{kg}$ cocaine in heterozygous BDNF knockout mice compared with wild-type littermates. Although there were no differences between the groups during the baseline period, BDNF knock-out mice were initially less sensitive than the wild-type mice to the locomotor stimulant effects of cocaine. Nevertheless, with repeated injections of cocaine (C1-C6), they did show the development of sensitization. Differences between the groups after repeated cocaine exposures compared with the habituation sessions was confirmed by an interaction between group and session $\left(F_{(5,35)}=2.82 ; p<0.01\right)$. After the first cocaine 
Intra-VTA BDNF infusions

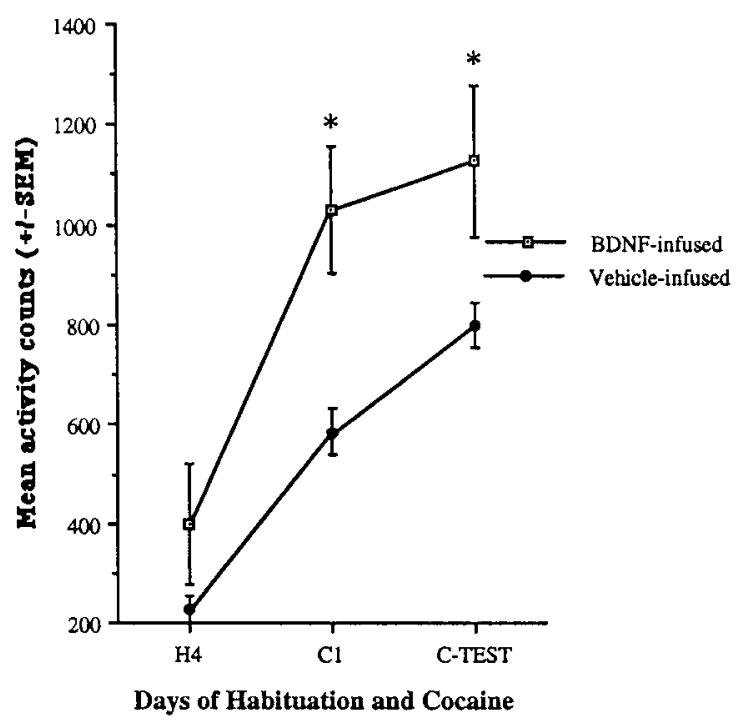

Intra-VTA NGF infusions

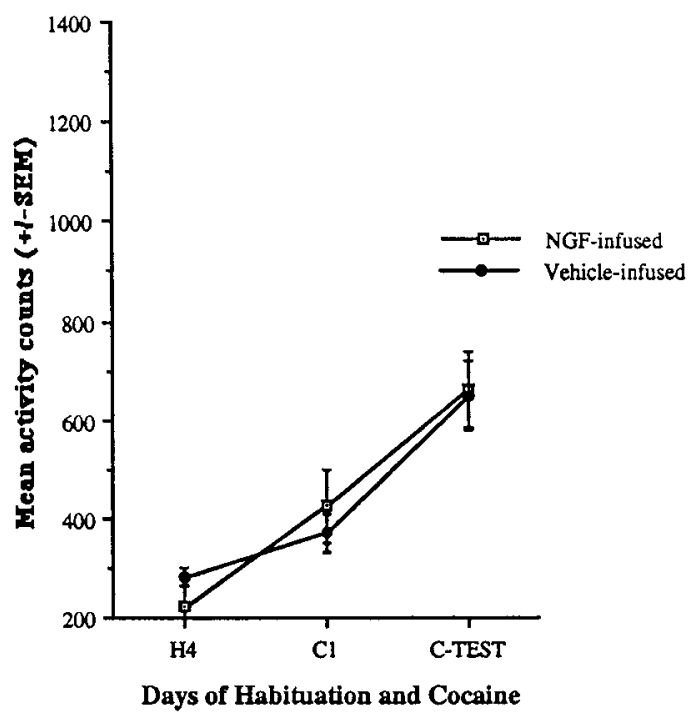

Figure 7. Effects of intra-VTA BDNF (left) or intra-VTA NGF (right) infusions on locomotor activation after $15 \mathrm{mg} / \mathrm{kg}$ cocaine. Intra-VTA BDNF-inf used animals $(n=13)$ showed a greater amount of activity compared with vehicle-inf used animals $(n=11)$ after the first $15 \mathrm{mg} / \mathrm{kg}$ cocaine injection (C1) and the final $15 \mathrm{mg} / \mathrm{kg}$ injection (C-TEST). Intra-VTA infusions of NGF $(n=5)$ did not result in activity counts that differed from vehicle-infused animals $(n=4)$ during habituation (H4), C1, or C-TEST. Both groups of vehicle-infused animals and NGF-infused animals showed sensitization to cocaine, whereas BDNF-inf used animals did not show a progressive increase in locomotor activity over the C1 and C-TEST session (see Results). Significant differences are shown for BDNF-inf used compared with vehicle-inf used animals; ${ }^{*} p<0.05$. Data are expressed as the mean \pm SEM number of photocell disruptions over the 30 min test period.

\section{Intra-NAc BDNF infusions}

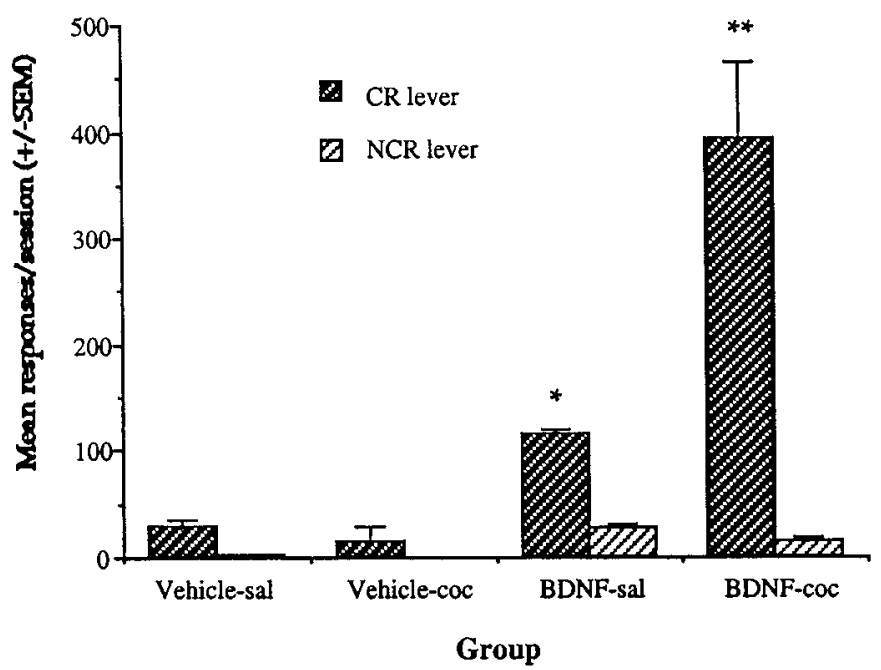

Figure 8. Effects of intra-NAc BDNF infusions on responding for CR. Enhanced responding for $\mathrm{CR}$ was found after intra-NAc BDNF inf usions. Intra-NAc BDNF infusions enhanced responding on the CR lever compared with animals given intra-NAc vehicle inf usions after a saline (sal) challenge test $\left(F_{(1,6)}=9.10 ; * p<0.02\right)$. After a cocaine $($ coc; $10 \mathrm{mg} / \mathrm{kg}$, i.p.) challenge, animals given intra-NAc BDNF infusions showed an even greater potentiated responding on the CR lever $\left(F_{(1,6)}=19.81 ; * * p<\right.$ 0.01 ). Responding on the control lever (NCR) was lower than the CR lever under all conditions.

challenge (C1), there was a significant difference between the groups; BDNF knock-out mice had activity rates that were $60 \%$ less than those of the wild-type littermate controls. Although the BDNF knock-out mice initially had lower activity rates, they eventually became sensitized to the $10 \mathrm{mg} / \mathrm{kg}$ dose of cocaine. Activity rates remained lower in BDNF knock-out animals over several sessions, but by the second cocaine injection (C2) there were no significant differences between the groups. No evidence of cocaine-induced stereotypy was observed. BDNF animals showed differences in habituation to the saline injections $\left(F_{(2,14)}=4.36 ; p<0.05\right)$, where on the final habituation session (H3; data not shown), their rates were lower $\left(F_{(1,7)}=12.45 ; p\right.$ $<0.01)$. As noted, BDNF knock-out mice were significantly heavier than the wild-type littermate animals, averaging $35.6 \mathrm{gm}$ (SEM 1.93) compared with 24.5 gm (SEM 0.67), respectively $\left(F_{(1,7)}=22.76 ; p<0.01\right)$.

\section{DISCUSSION}

The results of this study demonstrate that chronic infusions of BDNF into the mesolimbic DA pathway exert potent and longlasting behavioral effects. Intra-NAc or intra-VTA BDNF infusions increased locomotor activity and enhanced the development of locomotor sensitization to cocaine over a wide range of doses. Conversely, the heterozygous BDNF knock-out mice were initially less sensitive to the locomotor stimulant effects of cocaine than were the wild-type mice. Intra-NAc BDNF infusions also potentiated the ability of a stimulus to act as a CR and augmented cocaine-induced potentiated responding for CR. Potentiated responding for CR after cocaine challenge was seen up to 1 month after BDNF infusions. The potent actions of BDNF on mesolimbic DA function support the hypothesis (Berhow et al., 1995, 1996; Nestler et al., 1996) that BDNF and drugs of abuse may regulate the mesolimbic DA system, in part through converging cellular pathways.

The behavioral effects of BDNF seen in the present study are consistent with previous reports that BDNF enhances nigrostriatal DA function. BDNF augments striatal DA release and turnover (Altar et al., 1992, 1994) and induces behavioral changes, 


\section{Intra-NAc BDNF infusions}

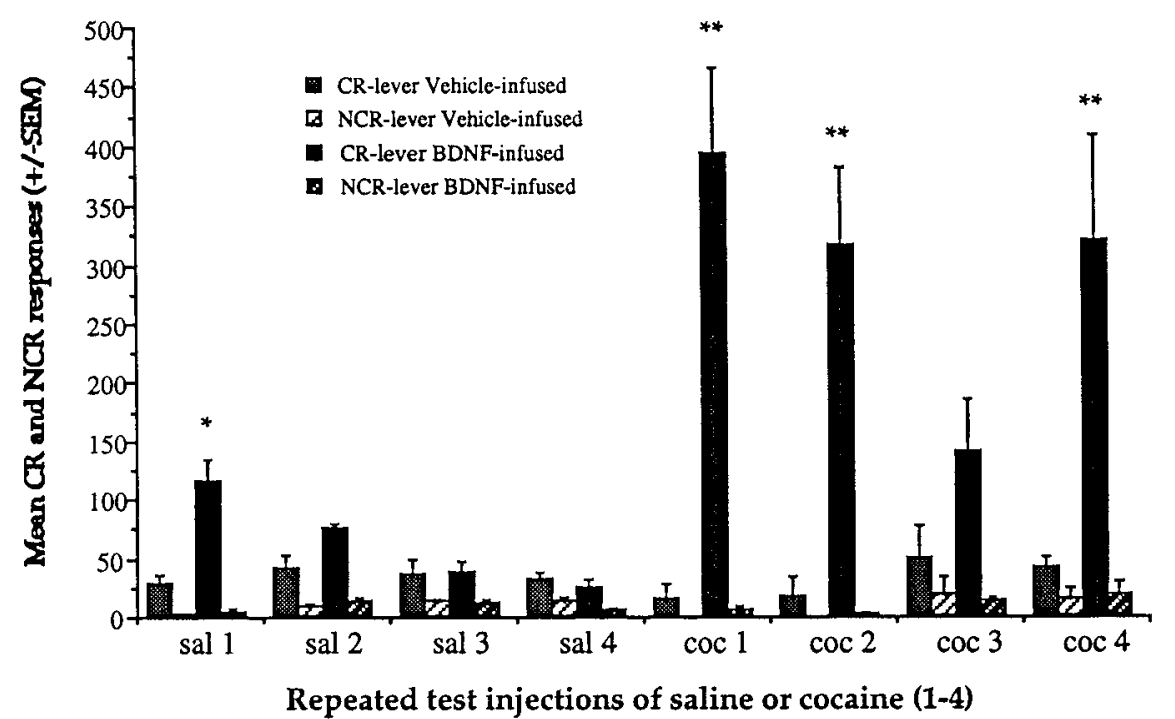

Figure 9. Long-term effects of intra-NAc BDNF infusions after saline or cocaine on responding for $\mathrm{CR}$ up to 5 weeks after cessation of BDNF administration. BDNF-infused animals showed enhanced responding for $\mathrm{CR}$. After the first saline infusion (sal1), there were differences between the groups on the levers; CR lever responses were increased in the BDNF-infused compared with the vehicle-infused group $\left({ }^{*} p<0.01\right)$. Similar effects were observed in sal2 in which there was a trend for a selective CR increase $\left(F_{(1,6)}=5.44 ; p=0.06\right)$. After subsequent saline (sal3-sal4) injections, only preferences for CR over the NCR lever were found. Responding on the CR lever was markedly increased and persisted in the BDNF-infused compared with the vehicleinfused animals after these cocaine challenges on days $\operatorname{coc} 1, \operatorname{coc} 2\left(F_{(1,6)}=19.81\right.$ and $\left.13.01 ; p<0.01\right)$, and $\operatorname{coc} 4\left(F_{(1,6)}=6.87 ; p<0.05\right)$, and there was a trend on coc3. Significant differences are shown as **. No differences in responding on the NCR lever were observed. Note that the data for sal 1 and coc1 are the same as depicted in Figure 8.

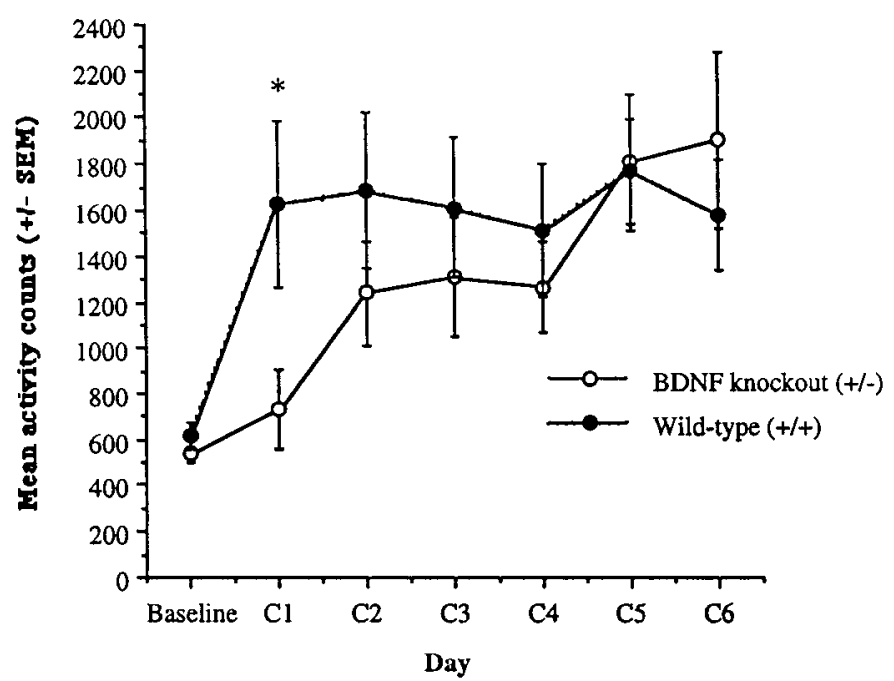

Figure 10. Development of sensitization after $10 \mathrm{mg} / \mathrm{kg}$ cocaine in BDNF knock-out mice. Heterozygous BDNF knock-out animals showed a delay in the development of sensitization compared with wild-type littermate control animals. Data are expressed as the mean \pm SEM number of photocell disruptions over the $30 \mathrm{~min}$ test period. BDNF knock-out animals $(n=5)$ showed a reduced amount of activity compared with littermate controls $(n=4)$ after the first $10 \mathrm{mg} / \mathrm{kg}$ cocaine injection (C1) but eventually became sensitized to cocaine. No differences between the groups were observed during baseline. Significant differences are shown for BDNF knock-out compared with wild-type littermate animals; $F_{(1,7)}=5.70 ;{ }^{*} p<0.05$.

indicative of increased DA release (Martin-Iverson and Altar, 1996). Notably, chronic supranigral BDNF increases the number of spontaneously active DA neurons and cell firing rates (Shen et al., 1994). In the present study, we found that low doses of BDNF achieve significant effects in the mesolimbic system (2 vs 12 $\mu \mathrm{g} /$ day), which is consistent with earlier biochemical studies (Berhow et al., 1995). Interestingly, basal levels of BDNF mRNA in the NAc and VTA are more than twofold higher than those in the striatum and substantia nigra (Hung and Lee, 1996).

BDNF-infusions have also been reported to induce weight loss in rodents, while increasing feeding and food retrieval (Lapchak and Hefti, 1992; Sauer et al., 1993; Pelleymounter et al., 1995; Martin-Iverson and Altar, 1996). In the current study, no consistent group effects on weight loss were found after infusion of lower doses of BDNF into the NAc; however, intra-VTA infusions did produce weight loss, and BDNF knock-out mice were heavier than their wild-type littermates. These data suggest that the site and dose of BDNF infusion may play a role in its effects on weight loss.

In the present study, BDNF infusions into the NAc or VTA appeared to increase the sensitivity to the locomotor-activating effects of a challenge dose of $15 \mathrm{mg} / \mathrm{kg}$ cocaine. It was also possible to show augmented sensitization to lower doses of cocaine in the NAc BDNF-infused animals. Such NAc infusions promoted the development of locomotor sensitization to a subthreshold cocaine dose $(5 \mathrm{mg} / \mathrm{kg})$, as well as to doses that normally can produce sensitization $(7.5-10 \mathrm{mg} / \mathrm{kg})$. Moreover, heterozygous BDNF knock-out mice showed delayed development of sensitization. Sensitization to cocaine is believed to be mediated by progressive increases in DA transmission (Kalivas, 1993) and alterations in intracellular signal transduction systems (Nestler and Aghajanian, 1997) in the VTA-NAc pathway. For example, intra-NAc infusions of agents that activate the cAMP pathway cause sensitization to cocaine or amphetamine (Cunningham and Kelley, 1993; Miserendino and Nestler, 1995). Together, these studies raise the possibility that intra-NAc infusions of BDNF enhanced the development of sensitization to the locomotor stimulant effects of cocaine by increasing the efficacy of DA neurotransmission in the VTA-NAc pathway.

Enhanced responding for $\mathrm{CR}$ after BDNF infusions is likely caused by increased DA neurotransmission in this same pathway. Compounds that enhance synaptic DA release strongly potentiate responding for CR (Beninger et al., 1981; Robbins et al., 1983; Cador et al., 1991; Kelley and Delfs, 1991b; Chu and Kelley 1992; Cunningham and Kelley, 1992; Phillips et al., 1994; Ranaldi and Beninger, 1995). Intra-NAc infusions of agents that activate the cAMP pathway also enhance responding for CR (Kelley and Holahan, 1997). Chronic cocaine exposure, which is known to upregulate the cAMP pathway in the NAc (Nestler and Aghaja- 
nian, 1997), similarly enhances responding for CR (Taylor and Horger, 1999). Although we cannot rule out diff usion of BDNF to nearby regions, the range of diffusion after intracerebral inf usion of BDNF is known to be highly limited (Berhow et al., 1995). Indeed, it is known that the NAc and surrounding ventrolateral striatum are critical sites for enhanced responding for CR (Taylor and Robbins, 1984, 1986; Cador et al., 1991; Kelley and Delfs, 1991a). The magnitude of responding on the CR lever in BDNFinf used animals after systemic cocaine was impressive; increases were 15- to 20-fold higher in BDNF-infused compared with vehicle-infused animals. Notably, this potentiation was selective to the incentive motivational effects of the CR stimulus (Taylor and Robbins, 1984), because no increases in control lever (NCR) responses were found.

In humans and laboratory animals, it is well known that drugtaking behavior can be maintained or reinstated not only by the primary reinforcing effects of drugs themselves but by external stimuli or factors that may come to act as CR through associative learning (Davis and Smith, 1974; De Wit and Stewart, 1981; Childress et al., 1988, 1992; Robbins et al., 1989; O'Brien et al., 1992; Shaham and Stewart, 1995). Conditioned stimuli predictive of drug state may thereby cause relapse to drug-seeking behavior. Investigation of the conditioned incentive-motivational effects of drugs is seen, therefore, as critical for understanding drug-seeking behavior and craving (Markou et al., 1993). Our data provide direct evidence that BDNF, via actions in the mesolimbic DA system, can potently augment the effects of cocaine on incentive motivation.

BDNF also affected mesolimbic DA function in response to mild stress. Intra-NAc BDNF increased saline-induced responding for CR and saline-induced locomotor activity. These effects, too, may be mediated by potentiated mesolimbic DA function. Stress is well known to activate DA neurons, and saline inf usions or injections can act as mild stresses. Furthermore, BDNFinf used animals were not basally hyperactive, because activity rates were never increased before a saline injection. Interestingly, after the BDNF infusion period, these effects of mild stress were no longer observed, whereas augmented drug-induced behavioral effects were long-lasting, as mentioned above.

$\mathrm{BDNF}$ is known to be retrogradely transported from nerve terminals to cell body regions after binding to the TrkB receptor (DiStefano et al., 1992; Bothwell, 1995) and, after intrastriatal infusions, BDNF is transported to the substantia nigra, where it is localized in DA-containing neurons (Mufson et al., 1994). Although BDNF and TrkB receptors are expressed in both the NAc and VTA, it is not clear whether BDNF acts locally in an autocrine manner in regions where it is synthesized or whether it is transported from the NAc to the VTA or vice versa. In contrast to the more pronounced behavioral effects of intranigral versus intrastriatal BDNF (Martin-Iverson et al., 1994), we found here that intra-NAc BDNF infusions were at least as potent as intraVTA infusions. Regardless of these possible sites of action, our results indicate that BDNF infusion into either site produced similar behavioral effects.

Presumably, the behavioral effects of BDNF demonstrated in the present study are mediated via long-term adaptations within the mesolimbic DA system induced by BDNF infusions. Our previous work has shown that BDNF prevents some biochemical and morphological changes in the VTA and NAc induced by chronic administration of cocaine or other drugs of abuse (Berhow et al., 1995, 1996; Sklair-Tavron et al., 1996). These observations, coupled with the current findings, suggest that these particular biochemical and morphological changes reflect tolerance to aspects of repeated drug exposure. According to this hypothesis, BDNF may prevent certain aspects of tolerance to cocaine and thereby produce an even greater behavioral response to the drug. A related possibility, which requires further research, is to determine whether BDNF infusions induce additional adaptations in the VTA-NAc pathway, which by themselves promote behavioral responses to drugs of abuse (Robinson and Kolb, 1997). Moreover, the finding that BDNF knock-out mice show delayed locomotor sensitization to cocaine suggests that, in addition to the ability of exogenous BDNF to modulate responses to cocaine, endogenous BDNF systems are required for the normal development of behavioral adaptations to this drug.

There is considerable interest in the potential clinical use of neurotrophic factors or agents that activate neurotrophic signaling pathways for the treatment of neurodegenerative diseases, such as Parkinson's disease (Lindsay et al., 1995). In this disease, the major pathological changes occur in the nigrostriatal DA pathway, while the mesolimbic pathway is relatively spared (Javoy-Agid et al., 1981). Given that the behavioral effects of BDNF on mesolimbic DA function are dramatic and tend to promote cocaine action, the results of the present study should raise caution with regard to the clinical use of certain neurotrophic factors or similarly acting agents.

\section{Conclusions}

These data provide behavioral evidence for overall enhancement of the psychomotor stimulant and rewarding effects associated with cocaine after infusion of BDNF into the mesolimbic DA system. Such enhanced functioning of the mesolimbic DA system was seen both under normal conditions (i.e., in response to mild stress) and in response to acute and repeated cocaine administration. We hypothesize that these effects are caused by long-term adaptations within the mesolimbic DA system and that endogenous BDNF systems may play a role in the long-term adaptations of the brain to cocaine.

\section{REFERENCES}

Altar CA, Boylan CB, Jackson C, Hershenson S, Miller G, Wiegand NJ, Lindsay RM, Hyman C (1992) Brain-derived neurotrophic factor augments rotational behavior and nigrostriatal dopamine turnover. Proc Natl Acad Sci USA 89:11347-113551.

Altar CA, Boylan CB, Fritsche M, Jackson C, Hyman C, Lindsay RM (1994) The neurotrophins NT-4/5 and BDNF augment serotonin, dopamine and GABAergic systems during behaviorally effective inf usions into the substantia nigra. Exp Neurol 130:31-34.

Beninger RJ, Hanson DR, Phillips AG (1981) The acquisition of responding with conditioned reinforcement: effects of cocaine, $(+)-$ amphetamine and pipradrol. Br J Pharmacol 74:149-154.

Berhow MT, Russell DS, Terwilliger RZ, Beitner-Johnson D, Self DW, Lindsay, RM, Nestler EJ (1995) Influence of neurotrophic factors on morphine- and cocaine-induced biochemical changes in the mesolimbic dopamine system. Neuroscience 4:969-979.

Berhow MT, Hiroi N, Nestler EJ (1996) Regulation of ERK (extracellular signal-regulated kinase), part of the neurotrophin signal transduction cascade, in the rat mesolimbic dopamine system by chronic exposure to morphine or cocaine. J Neurosci 16:4704-4715.

Bothwell M (1995) Functional interactions of neurotrophins and neurotrophin receptors. Annu Rev Neurosci 18:223-253.

Bozarth MA, Wise RA (1986) Involvement of the ventral tegmental dopamine system in opioid and psychomotor stimulant reinforcement. In: Problems in drug dependence (Harris LS, ed), pp 190-196. Washington, DC: US Government Printing Office.

Burns LH, Everitt BJ, Robbins TW (1994) Intra-amygdala infusion of the $N$-methyl-D-aspartate receptor antagonist AP5 impairs acquisition but not performance of a discriminated approach to an appetitive CS. Behav Neural Biol 61:242-250. 
Cador M, Taylor JR, Robbins TW (1991) Potentiation of the effects of reward-related stimuli by dopaminergic-dependent mechanisms in the nucleus accumbens. Psychopharmacology 104:377-385.

Childress AR, McLellan AT, Ehrman R, O’Brien CP (1988) Classically conditioned responses in opioid and cocaine dependence: a role in relapse? Natl Inst Drug Abuse Res Monogr 84:25-43.

Childress AR, Ehrman R, Rohsenow DJ, Robbins SJ, O'Brien CP (1992) Classically conditioned factors in drug dependence. In: Substance abuse: a comprehensive textbook, Ed 2 (Lowinson JW, Luiz P, Millman RB, Langard JG, eds), pp 56-69. Baltimore: Williams and Wilkins.

Chu B, Kelley AE (1992) Potentiation of reward related responding by psychostimulant infusion into nucleus accumbens: role of dopamine receptor subtypes. Psychobiology 153-162.

Cunningham ST, Kelley AE (1992) Evidence for opiate dependent cross-sensitization in nucleus accumbens: studies of conditioned reward. Brain Res Bull 29:675-680.

Cunningham ST, Kelley AE (1993) Hyperactivity and sensitization to psychostimulants following cholera toxin infusion into the nucleus accumbens. J Neurosci 13:2342-2350.

Davis WM, Smith SG (1974) Behavioral control exerted by an amphetamine based conditioned reinforcer. In: Neurobiology and influences on behavior, Vol 3, Drug addiction (Singh JM, Lal H, eds), pp 209-217. New York: Stratton.

de Wit H, Stewart J (1981) Reinstatement of cocaine-reinforced responding in the rat. Psychopharmacology 75:134-143.

DiStefano PS, Friedman B, Radziejieski AC, Boland P, Schick CM, Lindsay RM, Wiegand SJ (1992) The neurotrophin BDNF, NT-3, and NGF display distinct patterns of retrograde axonal transport in peripheral and central neurons. Neuron 8:983-993.

Everitt BJ, Robbins TW (1992) Amygdala-ventral striatal interactions in reward-related processes. In: The amygdala (Aggelton JP, ed), pp 401-409. New York: Wiley.

Frank L, Wiegand J, Siuciak JA, Lindsay RM, Rudge JS (1997) Effects of BDNF infusion on the regulation of TrkB protein and message in adult rat brain. Exp Neurol 145:62-70.

Hebert MA, Van Horne CG, Hoffer BJ, Gerhardt GA (1996) Functional effects of GDNF in normal rat striatum: presynaptic studies using in vivo electrochemistry and microdialysis. J Pharmacol Exp Ther 279:1181-1190.

Hiroi N, Brown JR, Haile CN, Greenberg ME, Nestler EJ (1997) FosB mutant mice: loss of chronic cocaine induction of Fos-related proteins and heightened sensitivity to cocaine's psychomotor and rewarding effects. Proc Natl Acad Sci USA 94:10397-10402.

Horger BA, Taylor JR, Elsworth JD, Roth RH (1994) Preexposure to, but not co-treatment with, the neurotensin antagonist SR 48692 delays the development of cocaine sensitization. Neuropsychopharmacology 11:215-222.

Horger BA, Nishimura MC, Armanini MP, Wang L-C, Poulsen KT, Rosenblad C, Kirik D, Moffat B, Simmons L, Johnson Jr E, Milbrandt J, Rosenthal A, Björklund A, Vandlen RA, Hynes MA, Phillips HS (1998) Neurturin exerts potent actions on survival and function of midbrain dopaminergic neurons. J Neurosci 18:4929-4937.

Hung H-C, Lee EHY (1996) The mesolimbic dopaminergic pathway is more resistant than the nigrostriatal dopaminergic pathway to MPTP and $\mathrm{MPP}^{+}$toxicity: role of BDNF gene expression. Mol Brain Res 41:16-26.

Hyman C, Hofer M, Barde Y-A, Jahasz M, Yancopoulos GD, Squinto SP, Lindsay RM (1991) BDNF is a neurotrophic factor for dopaminergic neurons of the substantia nigra. Nature 350:230-232.

Ip NY, Ibanez CF, Nye SH, McClain J, Jones PF, Gies DR, Bellusco L, Lebeau MM, Espinosa R III, Squinto SP, Perssen H, Yancopoulos GD (1992) Mammalian neurotropin-4: structure, chromosomal localization, tissue distribution and receptor specificity. Proc Natl Acad Sci USA 89:3060-3064.

Javoy-Agid F, Taquet H, Ploska H, Cherif-Zahar C, Ruberg M, Agid Y (1981) Distribution of catecholamines in the ventral mesencephalon of human brain, with special reference to Parkinson's disease. J Neurosci 36:2101-2105.

Kalivas PW (1993) Neurotransmitter regulation of dopamine neurons in the ventral tegmental area. Brain Res Rev 18:75-113.

Kalivas PW, Duffy P (1993) Time course of extracellular dopamine and behavioral sensitization to cocaine. I. Dopamine axon terminals. J Neurosci 13:266-275.

Kalivas PW, Stewart J (1991) Dopamine transmission in the initiation and expression of drug- and stress-induced sensitization. Brain Res Rev 16:223-244.

Kalivas PW, Sorg BA, Hooks MS (1993) The pharmacology and neural circuitry of sensitization to psychostimulants. Behav Pharmacol 4:315-334.

Kaplan DR, Hempstead BL, Martin-Zanca D, Chao MV, Parada LF (1991) The trk proto-oncogene product: a signal transducing receptor for nerve growth factor. Science 252:554-558.

Kawamoto Y, Nakamura S, Nakano S, Oka N, Akiguchi I, Kimura J (1996) Immunohistochemical localization of brain-derived neurotrophic factor in adult rat brain. Neuroscience 74:1209-1226.

Kelley AE, Delfs JM (1991a) Dopamine and conditioned reinforcement. I. Differential effects of amphetamine microinjections into striatal subregions. Psychopharmacology 103:187-196.

Kelley AE, Delfs JM (1991b) Dopamine and conditioned reinforcement. II. Contrasting effects of amphetamine microinjections into the nucleus accumbens with peptide microinjections into the ventral tegmental area. Psychopharmacology 103:197-203.

Kelley AE, Holahan MR (1997) Enhanced reward-related responding following cholera toxin infusion into the nucleus accumbens. Synapse 26:46-54

Koob GF (1992) Drugs of abuse: anatomy, pharmacology and function of reward pathways. Trends Pharmacol Sci 13:177-184.

Koob GF, Le Moal M (1997) Drug abuse: hedonic homeostatic dysregulation. Science 278:52-58.

Korte M, Carroll P, Wolf E, Brem G, Thoenen H, Bonhoeffer T (1995) Hippocampal long-term potentiation is impaired in mice lacking brainderived neurotrophic factor. Proc Natl Acad Sci USA 92:8860-8865.

Kuhar MJ, Ritz MC, Boja JW (1991) The dopamine hypothesis of the reinforcing properties of cocaine. Trends Neurosci 14:299-302.

Lapchak PA, Hefti F (1992) BDNF and NGF treatment in lesioned rats: effect of cholinergic treatment on weight gain. NeuroReport 3:405-408.

Liebman JM, Cooper SJ (1989) The neuropharmacological basis of reward (Liebman JM, Cooper SJ, eds). New York: Oxford UP.

Lindsay RM, Wiegand SJ, Altar CA, DiStefano PS (1995) Neurotrophic factors: from molecule to man. Trends Neurosci 17:182-189.

Loughlin SE, Fallon JH (1993) Neurotrophic factors. New York: Academic.

Mackintosh NJ (1974) The psychology of animal learning. London: Academic.

Markou A, Weiss F, Gold LH, Caine SB, Schulteis G, Koob GF (1993) Animal models of drug craving. Psychopharmacology 112:163-182.

Martin-Iverson MT, Altar CA (1996) Spontaneous behaviors of rats are differentially affected by substantia nigra infusion of brain-derived neurotrophic factor and neurotrophin-3. Eur J Neurosci 8:1696-1706.

Martin-Iverson MT, Todd KG, Altar CA (1994) Brain-derived neurotrophic factor and neurotrophin-3 activate striatal dopamine and serotonin metabolism and related behaviors: interactions with amphetamine. J Neurosci 14:1262-1270.

Miserendino MJ, Nestler EJ (1995) Behavioral sensitization to cocaine: modulation of the cyclic AMP system in the nucleus accumbens. Brain Res 674:299-306.

Mufson EJ, Kroin JS, Sobreviela T, Burke MA, Kordower JH, Penn RD, Miller JA (1994) Intrastriatal infusions of brain-derived neurotrophic factor: retrograde transport and colocalization with dopamine containing substantia nigra neurons in rat. Exp Neurol 129:15-26.

Nestler EJ, Aghajanian GK (1997) Molecular and cellular basis of addiction. Science 278:58-63.

Nestler EJ, Berhow MT, Brodkin ES (1996) Molecular mechanisms of drug addiction: adaptations in signal transduction pathways. Mol Psychiatry $1: 190-199$.

Numan S, Seroogy KB (1997) Increased expression of trkB mRNA in rat caudate-putamen following 6-OHDA lesions of the nigrostriatal pathway. Eur J Neurosci 9:489-495.

O'Brien CP, Childress AR, McLellan T, Ehrman R (1992) A learning model of addiction. In: Addictive states (O'Brien CP, Jaffe JH, eds), pp 157-177. New York: Raven.

Paxinos G, Watson C (1982) The rat brain in stereotaxic coordinates. New York: Academic.

Paxinos G, Watson C (1997) The rat brain in stereotaxic coordinates. New York: Academic.

Pelleymounter MA, Cullen MJ, Wellman CL (1995) Characteristics of BDNF-induced weight loss. Exp Neurol 131:229-238.

Phillips GD, Robbins TW, Everitt BJ (1994) Mesoaccumbens dopamine- 
opiate interactions in the control over behaviour by a conditioned reinforcer. Psychopharmacology 114:345-359.

Ranaldi R, Beninger RJ (1995) Bromocriptine enhancement of responding for conditioned reward depends on intact D1 receptor function. Psychopharmacology 118:437-443.

Robbins TW (1978) The acquisition of responding with conditioned reinforcement: effects of pipradrol, methylphenidate, $d$-amphetamine and nomifensine. Psychopharmacology 58:78-87.

Robbins TW, Watson BA, Gaskin M, Ennis C (1983) Contrasting interactions of pipradrol, $d$-amphetamine, cocaine, cocaine analogues, apomorphine and other drugs with conditioned reinforcement. Psychopharmacology 80:113-119.

Robbins TW, Cador M, Taylor JR, Everitt BJ (1989) Limbic-striatal interactions in reward-related processes. Neurosci Biobehav Rev 13:155-162.

Robinson TE, Berridge KC (1993) The neural basis of drug craving: an incentive-sensitization theory of addiction. Brain Res Rev 18:247-291.

Robinson TE, Kolb B (1997) Persistent structural modifications in nucleus accumbens and prefrontal cortex neurons produced by previous experience with amphetamine. J Neurosci 17:8491-8497.

Sauer H, Fischer W, Nikkhah G, Wiegand SJ, Brundin P, Lindsay RM, Björklund A (1993) BDNF enhances function rather than survival of intrastriatal dopamine cell-rich grafts. Brain Res 626:37-44.

Schmidt-Kastner R, Wetmore C, Olson L (1996) Comparative study of brain-derived neurotrophic factor messenger RNA and protein at the cellular level suggests multiple roles in hippocampus, striatum and cortex. Neuroscience 74:161-183.

Seroogy K, Gall C (1993) Expression of neurotrophins by midbrain dopaminergic neurons. Exp Neurol 124:119-128.

Shaham Y, Stewart J (1995) Stress reinstates heroin self-administration behavior in drug-free animals: an effect mimicking heroin, not withdrawal. Psychopharmacology 119:334-341.

Shen RY, Altar CA, Chiodo LA (1994) Brain-derived neurotrophicfactor increases the electrical activity of pars compacta dopamine neurons in vivo. Proc Natl Acad Sci USA 91:8920-8924.
Shults CW, Matthews RT, Altar CA, Langlais PJ (1994) A single intramesencephalic injection of brain-derived neurotrophic factor induces persistent rotational asymmetry in rats. Exp Neurol 124:119-128.

Siuciak JA, Boylyn B, Fritsche, Altar CA, Lindsay RM (1996) BDNF increases monoaminergic activity in rat brain following intracerebroventricular or intraparenchymal administration. Brain Res 710:11-20.

Sklair-Tavron L, Shi W-X, Lane SB, Harris HW, Bunney BS, Nestler EJ (1996) Chronic morphine induces visible changes in the morphology of mesolimbic dopamine neurons. Proc Natl Acad Sci USA 93: 11202-11207.

Spina MB, Squinto SP, Miller J, Lindsay RM, Hyman C (1992) Brainderived neurotrophic factor protects dopamine neurons against 6-hydroxydopamine and $\mathrm{N}$-methyl-4-phenyl-pyridinium ion toxicity: involvement of the glutathione system. J Neurochem 59:99-106.

Stephens RM, Loeb DM, Copeland TD, Pawson T, Greene LA, Kaplan DR (1994) Trk receptors use redundant signal transduction pathways involving SHC and PLC- $\gamma 1$ to mediate NGF responses. Neuron 12:691-705.

Taylor JR, Horger BA (1999) Enhanced responding for conditioned reward produced by intra-accumbens amphetamine is potentiated after cocaine sensitization. Psychopharmacology 142:31-40.

Taylor JR, Robbins TW (1984) Enhanced behavioral control by conditioned reinforcers following microinjections of $d$-amphetamine into the nucleus accumbens. Psychopharmacology 84:405-412.

Taylor JR, Robbins TW (1986) 6-Hydroxydopamine lesions of the nucleus accumbens, but not the caudate nucleus, attenuate enhanced responding with reward-related stimuli produced by intra-accumbens $d$-amphetamine. Psychopharmacology 90:390-397.

Vaidya VA, Siuciak JA, Du F, Duman RS (1999) Mossy fiber sprouting and synaptic reorganization induced by chronic administration of electroconvulsive seizures: role of BDNF. Neuroscience 89:157-166.

Winer BJ (1974) Statistical principles in experimental design, Ed 2. New York: McGraw Hill.

Wise RA, Bozarth MA (1987) A psychomotor stimulant theory of addiction. Psychol Rev 94:469-492. 